\title{
乳歯生活歯髄切断後の創傷治癒に関する病理組織学的研究
}

\author{
九州菌科大学口腔病理学講來（指導：上野正康教授） \\ 九州歯科大学小児歯科学講來（指導：木村光孝教挼） \\ 米村 博文 \\ 昭和55年11月25日受付
}

本論文の妿旨は，昭和55年 5 月15日第18回春季日本小児菌科学会総会，昭和 55 年 6 月15日第40回 九州柬科学会総会, 昭和55年 6 月28日第72回日本菌科保仔学会ならびに䀡和55年11月26日九州囦科 学会例会に扔いて発表した。

\section{Histopathological Studies on the Healing Process of Wound Following Vital Pulpotomy of Deciduous Teeth \\ Hirohumi Yonemura}

Department of Oral Pathology (Director: Prof. Masayasu Ueno)

Department of Pedodontics (Director: Prof. Mitsutaka Kimura)

Kyushu Dental College, Kitakyushu, Japan

Giving vital pulpotomy on deciduous teeth, taking paste-type Calcipulpe out of calcium hydroxide and paste-type Propac and Topdain from zinc oxide eugenol, the teeth were examined histopathologically on healing process of wound following the vital pulpotomy of deciduous teeth.

The results were as follows:

1. Forming of necrosis layer observed on the part given vital pulpotomy is comparatively extensive in area in the case of Calcipulpe and slight or sometimes none in the case of Propac and Topdain.

2. In the case of Calcipulpe on 21st day many pieces of calcium, large and small appear in the necrosis layer and show positive reaction on von Kóssa. In the case of Propac and Topdain any sign of such active reaction can not be observed.

3. On the boundary area between the necrosis layer and the normal pulp in the case of Calcipulpe from 14 days to 21 days after operation, a crystalized thick layer appears and shows active von Kóssa reaction as a boundary line. This fact doesn't agree with the result which was reported by investigaters who used calcium hydroxide in former days. At this stage a calcareous layer is formed right under the layer of von Kóssa reaction. Spindle cells, big cells or irregular cells are observed in the pulp circular cells and collagen fiber is enriched among cells.

4. In the case of Propac and Topdain, which are zinc oxide eugenol, a boundary line doesn't appear, but there is an accumulated inflammatory cell layer and forming of abscess is sometimes recognized in the layer. However granulation tissue with fibrous nature increases remarkably and becomes fibrous gradually towards lower 
part. Thus it shows that forming of hard tissue is impossible when no boundary line appears.

5. After 92 days in the case of Calcipulpe, a rough calcificated barrier as collagen fibrous matrix partly remains in reddish purple or light red color by gilt staining or Elastica van Gieson staining. Forming of a thick dentine barrier follows. In some parts of the dentine barrier reticular fiber invades from the pulp. This reticular fiber is similar to Korff's fiber and relates to the wall of root canal. In the case of Propac and Topdain from 14 th day to 21 st day, it becomes fibrous and this condition continues after 92 days.

6. When a lump of powdered dentine enters into the pulp, it takes the form of osteoid dentine if the pulp is vital, regardless of the agent used. This fact shows that it is not formed by the action of agent and it gives a suggestion for the future investigation.

7. From the above histopathological observation, Calcipulpe seems to be useful for a pedodontic clinic but Propac and Topdain are not so effective.

\section{緒}

言

歯髄は中胚葉に由来する疎な結合組織の塊であって， 血管，神経が豊富で，歯㵦基質と線維と細胞に区別さ れ，硬組織により囲まれている。乳雬は一般に永久荬に 比べ㐘髄腔は広く，菌根の吸収という生理的な特徽を有 しており，後継永久雨とスムーズに交換されなければな らない事は周知の通りである。そこのめには，乳雪のう 蝕は早期に治療されなければならない。

さて, 乳雪う蝕の羅患率は昭和 50 年度の厚生省の歯科 疾患実態調查によると，3歳児84.2\%，6 歳児で97.8\% と幼児期から学童期にかけて激增の傾向を示している 1). しかも日常の小児歯科臨床に打いてう蝕の治療に際

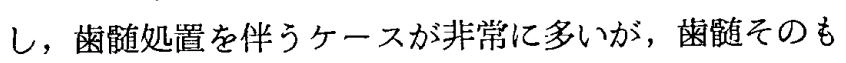
のの生活力が極めて旺盛であるため生物学的に可及的に 歯噵を保存する，いわゆる生活歯蹎切断処置がかなり頻 繁行われ，臨床ではかなり高い成功率を收めていると いわれている．従来から生活菌髄切断処置に使用される 覆骮剂は乳歯, 永久雪を問わず古くから水酸化カルシウ ム製剂, 酸化亜鉛ユージノール製剤が主で粉末と液を練 和することによりパスタ状あるいはペースト状になる楽 郕が使用されて来た。しかし, 近年, 楽剤の開発, 改良 が進みペースト・ペーストタイプのものを練和すること によりセメント状に硬化するような成分抢よび性状を異

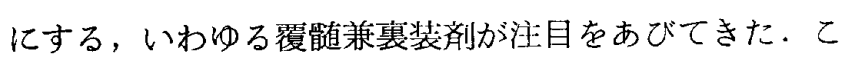
のように歯科臨床で使用されている覆㵦剂には粉末と夜
を練和するもの，ペースト・ペーストタイプのものを練 和して使用するもの，あるいはシリンジけに封入され， このシリンジより押し出すことにより，直接菌髄に作用 させるぺースト状のものなどがある.しかし，永久䨑の

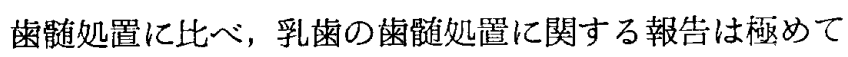
少ない。しかも，臨床あるいは臨床病理学的な報告は少 しは見られるが，病理組織学的な報告はほとんど見られ

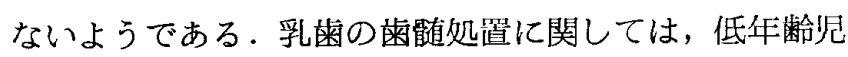
であることを考えると, 従来から使用されている粉末と 液を練和する覆蹃郕に比ベシリンジからそのままぺース ト状のものを苗䯠創面に作用させるものやペースト・ペ 一ストタイプのものを練和し，セメント状江硬化する覆

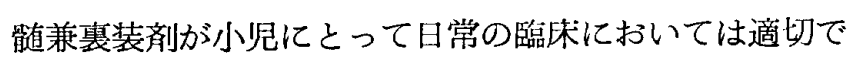
あると考えられる。しかし，病理組織学的には何ら解明 されていない，そこで著者は，水酸化カルシウム製剤か ら Calcipulpe，酸化亜鈆ユージノール製剤から Propac および Topdain を選択し，乳雪の生活菌髄切断 処置後の歯㖪創傷面の治痖機転に関して病理組織学的に 検索を行った結果，興味ある知見を得たので報告する。

\section{研究材料ならびに研究方法}

\section{1. 研究材料}

研究材料は 7 歳から 10 歳前後の小㸺患者から得られた 乳菡で，咬合誘導のため便宜抜去が必要之涪断されたも ので，とくに乳犬歯，第 1 乳歯で患者の協力を得たも のである、乳霜を選択するにあたっっては, 臨休的には自 
覚症状, 他覚症状など全くみられない健康歯で, 乳茵根 の吸収状態を観祭するにあたっては年㱓，X線款查，そ の他諸検査を十分把握した後, 乳歯根の吸収状態が著し く進行している歯牙は本研究からは除外した。覆喣剤は 水酸化カルシウム製剤からは Calcipulpe，酸化两鉛工 ージノール製威加ら゚ースト・ペーストタイプの Propac および Topdain を用いた. 本研究に使用した菂 凨の処方については次に示している通りである。

(1) Calcipulpe (Septodont Co., Paris) Calcium hydroxide $20.0 \mathrm{~g}$ Barium sulfate $20.0 \mathrm{~g}$ P-Hydroxybenzoic acid $0.1 \mathrm{~g}$ methyl ester

Excipient $100.0 \mathrm{~g}$

(2) Propac (G-C Co., Japan)

Base)

$\begin{array}{lr}\text { Zinc oxide } & 68 \% \\ \text { Olive oil } & 27 \% \\ \text { Terpentine oil } & 5 \% \\ \text { Accelerator) } & \\ \text { Rosin } & 50 \% \\ \text { Canada balsam } & 15 \% \\ \text { Eugenol } & 35 \%\end{array}$

(3) Topdain (Showa Yakuhin Kako Co., Japan)

\begin{tabular}{|c|c|c|c|}
\hline \multirow[t]{4}{*}{ (A) } & $20 \mathrm{~g}$ & Composition & $(\mathrm{g} / 1 \mathrm{~g})$ \\
\hline & & Zinc oxide & 0.763 \\
\hline & & Olive oil & 0.235 \\
\hline & & Zinc acetate & 0.002 \\
\hline \multirow[t]{3}{*}{ (B) } & $10 \mathrm{~g}$ & Composition & $(\mathrm{g} / 1 \mathrm{~g})$ \\
\hline & & Clove oil & 0.393 \\
\hline & & Rosin & 0.607 \\
\hline
\end{tabular}

2. 研究方法

小児䰹科臨床の通法に従って，研究部位を小児用デン タルフイルムで撮影したのち，2\%Xylocain 注射液 によって浸潤麻酔を行い除痛を行ったのち，日腔内を 3 $\%$ 過酸化水素水で十分清掃消毒したのち, 簡易防湿下， またはラバーダム防湿下にで，500,000rpm エアーター ビンおよび $18,000 \mathrm{rpm}$ 低速エンジンを用いて笾室を開 拡し， $3 \%$ 過酸化水素水または滅菌生理食塩水を用いて

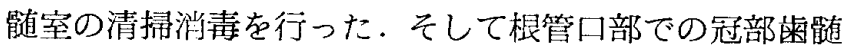
除去にはメルファラウンドバー（No.3からNo.6）を 用いた。次に $3 \%$ 過酸化水素水に浸した綿球で創面を数 回洗浄し, 最後に滅菌生理食塩水にて清掃し, 乾燥した
綿球を歯骮有切断面に軽く圧接し切断部の止血を行った。

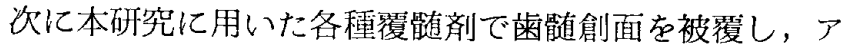
マルガム充填を施して切断手術を完了した。手術完了直 後, 小胃用デンタルフイルムにて撮影を行いすべてを完 了した．生活歯㕼切断ののち病理組織学的検索にあたつ ては，1日，3日，7日，14日，21日，35日，92日経過 後抜去し，直ちに10\%中性ホルマリン液で固定し，5\% 硝酸脱灰を行い，通法に従ってセロイジン包埋ののち $15 \lll$ 連続切片標本を作製した。

本研究に使用された染色法は次の通りである。
1) Hematoxylin Eosin 重染色
2) Elastica van Gieson 染色
3）渡辺鏝銀染色
4) von Kóssa 硝酸銀法
以上の各種染色法を施して鏡検した。

\section{病理組織学的所見}

\section{1 、水酸化カルシウム製剂 \\ Calcipulpe}

術後 1 日

歯髄切断部にはほとんぞ薬剤の残存はみられない，そ の直下には広範囲にわたって eosin に染まる均質無構 造な壊死層の形成が認められる。鎬銀染色では黒紫色 に, Elastica van Gieson 染色では黄赤色に染色され ているのが明膫である，壊死風内には hematoxylin に濃染された大小の石灭塊が類円形をなして所々に散在 している.乙の石灰塊は, 鋹銀染色では黒紫色に，Elastica van Gieson 染色では赤色を呈し,von Kóssa 硝 酸銀法では陽性に反忘することから, 以下 von Kóssa 陽性反応之略記する。図 1 亿示しているように壊死層内 には比較的小さな数個の石灰塊が，その周囲のとくに表 㬝部では濃く茶褐色として散在しているのが明膫に認め られる. 壊死層と健康菌髄之の境界部には分界線の出現 はなく，歯髄表風部には限局した軽度の炎症性細胞がみ られ，血管の充血が著明である。象牙牙細胞層は一部消 失しているが，下方に行くに従って正常構造を保ってお り何ら著変をみない。

歯喣切断部には多量の薬剤の残存がみられる例であ る、薬剤に接して辺縁部より歯能有中央部まで連続して壊 死層の形成があるが，辺縁部では強く，雬䯑道中央部では

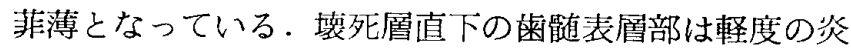
症性紐胞浸潤がみられる。炎症巣は鍍銀染色では濃紫色 を呈し, Elastica van Gieson 染色では黄赤色江染色 され，一般にその部ではほとんど膠原線維は諗められな 
いが,一部念珠状変性や断片化した線維組織が散見され る.

\section{術後 3 日}

柬䯣切断部には僅かながら莧剤の残存が認められる。 薬剂に接して広範囲に壊死層の形成が認められる。壊 死層は，鐘銀染色では黒紫色あるいは赤紫色を呈し， Elastica van Gieson 染色では赩あるいは黄赤色を 呈している．壊死層内には数個の石灰塊が散見され， hematoxylin に濃染されておうり，von Kóssa 陽性反 応として認められる．壊死層の内側には，硝子様化が認 められ，鍍銀染色では紫色, Elastica van Gieson 染 色では淡赤色として認められ，その部分では線維組織は 不明膫となっている。また硝子様化が起っている部分 は，顆粘状の石灭沈着が起っている，壊死層直下の歯鹃 よりの膠原線維は，鎴銀染色では紫色を呈し比較的太く 束状をなし，また Elastica van Gieson 染色では淡 赤色として束状をなしており，うねりながら盂死層に向 って不明膫となっている(図 $2 \sim 5$ ).

本例では歯髄切断部には薬剤の残存はほとんどなく， その直下には広範囲に壊死層の形成がある．壊死首と健 康歯髄との境界部には限局した細胞浸潤がみられる。そ の内側には軽度の充血がみられる，やや下方の歯蹎には 一部硝子様化が起っている。

雪髄切断部直下には広範囲に壊死層の形成が認められ る例であるが，壊死層内には顆䊀状の大きな石灰塊が辺 縁部に数個認められるのみである. 雪髄表層部には比較 的強い充血と軽度の出血，および炎症性細胞浸潤があ

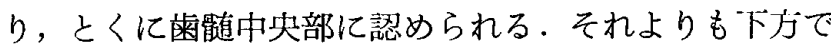

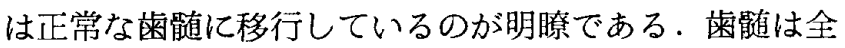
般的に充血調を呈している。

術後 7 日

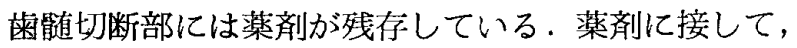

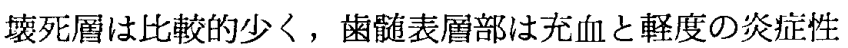
細胞浸潤が認められ，下方の㐘髄は，ほほ正常像を呈し ているが一部石灰変性が認められる.

本例では歯髄切断面には薬剤は認められない，切断面

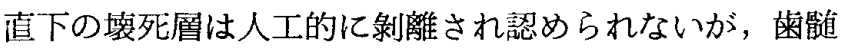

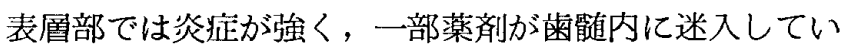
る所がみられる。薬剤の周囲には比較的炎症は少く，部 分的ではあるが，幼若な肉芽組織の増殖が認められる。 それより下方の曾骮遖には炎症はなく，ほぼ正常像を保っ ている。

術後14日

歯髄切断部には薬剤の残存が認められる。薬剤に接し
て軽度の庻死層が認められ，とくに辺縁部において著明 である．壊死凮と健康歯観との境界部では分界線の出現 は認められるが，とくに菊蹎中央部では不明睹となって

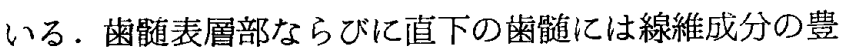
富な所見を呈し，線維が密集している所では一部で基質 化の様相を呈し石灰化の初期の所見として認められ，歯 髄に接して類円形細胞，紡鍾形細胞が琶められる．下方 の蒾髄はほぼ正常像を呈し，何ら著変は認められない。

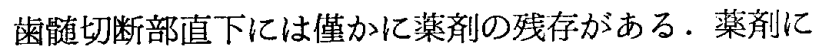
接して広範围な壊死首の形成があり，烄死層内には比較 的大きな数個の石灰塊が認められる．壊死層と健康歯髄 との境界部には凹凸不整の顆粒状の石灭塊が一部不明膫 な部分を除いて，辺縁部から歯跹中央部に向って連続し て分界線として明膫汇諗められる.von Kóssa 陽性反 床では，分界線は結晶状をなして茶褐色に染色されてい る. 図 6 亿示すように, 分界線直下の菊髄には膠原線維 が豊富で密集し，石灰化初期の様相を呈している．やや

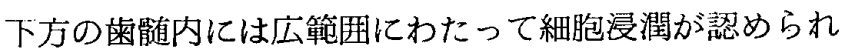
る、鍍銀染色によると，壊死風内には既存の線維成分が 今だ琶められる所もある．石灰化の样相を呈している部 では，黒紫色をなした膠原線維が密集しているが歯值よ りの好銀性を帯びた線維組織の侵入も想められる《図 $7)$. Elastica van Gieson 染色では, 壊死層内の石 灰塊は赤色を呈し, 分界線は濃紫色に染色されている. 石灭化開始の部では, 膠原線維が密集して淡赤色に染色 された所も誋められる(図8).

本例では，歯髄切断部直下の壊死層と健康歯髄との境 界部には von Kóssa 陽性反心として茶褐色を呈した 結晶状の物質が分界線として一層を形成している，von

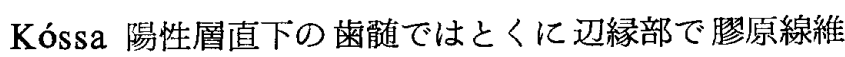
が密集し,石灰化の様相を呈し, Elastica van Gieson 染色では膠原線維が豊富であるのが明瞭である。しか し，歯㕼中央部の一部では今だ宩䯕組織がみられ，血管 が残存している所もみられる.

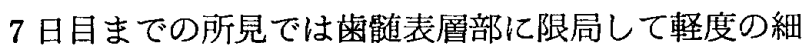
胞浸潤が認められたが，14日目の所見においては 1 例を 除いて炎症所見はほとんぞ消失している．14日目頃まで の所見をみた限りでは，分界線の出現はあるが，辺縁部 から蒾此道中央部に連続した典型的な分界線は諗められな W.

\section{術後21日}

䨑檤切断部には極く僅かながら薬剤の残存が認められ る。薬剤に接して広轮囲に壊死層の形成がある．壊死層 内には類円形をなした大小の顆粒状の石㕄塊が多数散見 


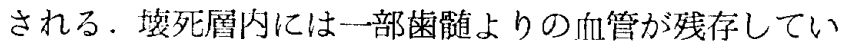

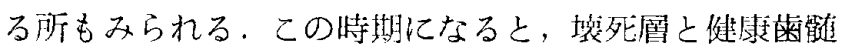
との境界部は14日目に比心忑速に明唣となっており, 讱 縁部から畨梿中央部に連続して分界線の出現が著明であ る. hematoxylin に濃染されて涩められる。直下の柬

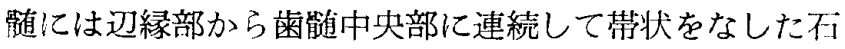
灭化層が明嘹となっている，石圧化層内には一部菌髄や 咱管，小孔が埋入している所もみられる．石圧化層に接 した歯骫には，秒鉃形細胞，類円形細胞，大型の細胞，

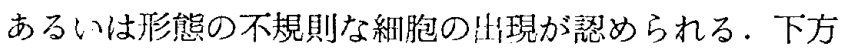
の夹䯠は全般に㲹管の昖張，充伅はみられるが正常像を 品している。象牙芽細胞層にも，何ら著変は認められな い（図 9，10．21日経過例では，とくに切断面を von Kóssa 陽性反忘でみると, 墑死風内の大小不同, 類円 形をなした茶褐色の結晶状の顆粒は中心部は茶褐色でそ の周囲とくに表層部は赤褐色として認められる．また，

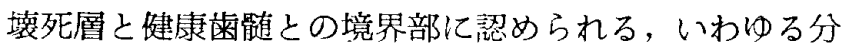
界線上の顆粒状の結晶は密集し, 辽縁部汃ら畨醚中央部 に連続してとくに茶褐色として著明に涩められる（図 11，12，般銀染色によると, 壊死層と健康蔽髄との分 界線は境界明膫に濃赤紫色を呈し, von Kóssa 陽性反 心に相当する部で明らかに区別出来る．直下の不灭化層 は赤紫色を呈し，不庅化層には束状をなした膠原線維が 珰められ，中に血管が埋入した所もみられる。また，蒾 链よりの微細な好銀線維の侵入している所もみられる (図13). Elastica van Gieson 染色では, 壊死層と健 康菌㵦との分界線は赤色を呈し, 直下の石灰化層には边

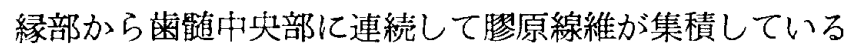
のが明瞭である(図14)。

本例では菌膸切断部にはほとんど楽剂の残存は認めら れない，その直下の壊死周もほとんどみられない，柬䯚 表層部から菌髄内に連続して象牙質削片が迷入してお り，それを核として骨様象牙質形成開始の所見が認めら れる。そその周囲には炎症性練胞浸潤は認められず，線維 が豊富にみられる.やや下方の歯髄はほぼ正常像を呈し ている.象牙芽細胞は規則正しい配列を示している.

歯髄切断部直下には，一部崡髄中央部では象牙質削片 が迷入している所と，辽緣部では膠原線維性基質として の石灰化層とが一緒に羿められる所見を呈している．石 灭化層内には，歯髄よりの血管が迷入している所や小管 が琶められる所などがある．象牙質削片が迷入している 所では菲薄ではあるが骨橡象牙質の形態をとっているの が明瞭である。

囷能有切断部が根管下部できれいに切断されていると思
われる例であるが，莧剤に接して菲薄な壊死層の形成が

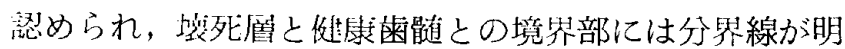
源である，その直下では，膠宗線維が豊富で基兵化の栏 相を呈しており典型的な不成化層を形成している．不灰

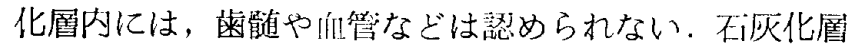

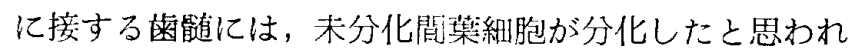
る絊胞が密に並んでいる所もみられ，一部には大型の絧 胞も散見される、根管曾髄には何ら著変はなく，象牙牙 細胞も規則正しい配列を示しているのが明瞭である。

術後35日

歯能切断部に多量の薬剂が残存している例である。薬 剤に接して，広範囲ではあるが菲薄な㳖死層の形成が認 められる。乙の時期になると，21日目迄みられた壊死層 内の顆粒状の石灭塊は散見されない，また，分界線上に 琶められる von Kóssa 陽性反応を示す層は，鍍銀染 色では好銀性を帯びた線維としてみられる，㙗死層直下 には，21日目より更に切断面の治癒は進行し，一部では 線維形態の粗い石灭化圈を残した所もみられ，均等では ないが象牙質柵の形成が浔められる所では鋅銀染色で線 維性基質として䛱められる。象牙質柵はとくに辺緣部で 厚く形成され，それに伴って一部では奻苦象牙質の形成 も諗められる。

本例では歯辅通切断部には薬剂の残存は全くみられな い，苗骾表層部には，軽度の炎症性細胞浸潤ならびに網 様萎縮所胃がみられる。歯䯚队には，一部薬凨が落ち込 んでいる所や，図15にみられるように佬牙䁈削片が迷人 してそれを核として形成されたと思われる骨様象牙䨘の 形成が歯髄組織を介在して認められる，胃様象牙質の周

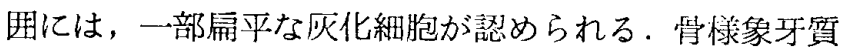
の中心は，核として認められる所がとくに hematoxylin に濃染されて散見される所がある.鍍銀染色では， 骨様象牙質は黑紫色に染色され，雬霜よりの膠原線維に より取り囲まれている所や骨椂象牙質から逃れるような

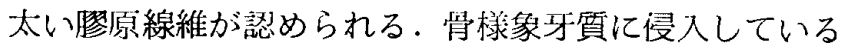
線維組織は比較的微細な好銀線維として䜑められる（図 16). Elastica van Gieson 染色では，骨様象牙質は 赤色に染色され，その周囲には膠原線維が密集している 所もみられる（図17）。下方の函骮有は全体的に血管の抾 張，充血の他は何ら著変は認められない.

切断面には薬剤の残存が諗められる例である．㵦腔壁 では，象牙質柵の形成が諗められるが辺縁部から菌㔠迶中 央部に連続したものではなく，歯䯣中央部には，まだ歯 髄組織がみられ，そこには充血も著明である。

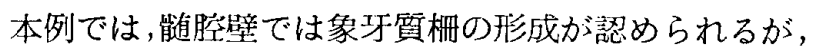


歯髄中央部ではまだ石灭化層がみられる，その直下では 線維成分に富んだ所見を呈しているが，下方に行くに従 つて正常な霜䇴に移行しているのが明䐲である.てのよ うに35日経過例においては，象牙䨘柵あるいは骨様象牙 䨘が均等性ではないが翟められる．また，石灰化層とし て琾められている所む象牙質柵になると思われる所胃を 呈している.

術後 92 日

歯殉道切断部直下に菲薄はな壊死層の形成がみられる。 それに接して膠原線維性基質としてての粗い石兏化柵が一 部残存しているのが珰められる. 石灭化䒽に連続して厚 い幅広い象牙質柵の形成が琹められ，根管壁に形成され た象牙質と組織癒合が行われ，ほぼ同程度の染色性を示 して匊髄組織を被覆保護しているのが明暩である。象牙

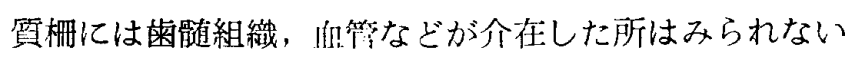

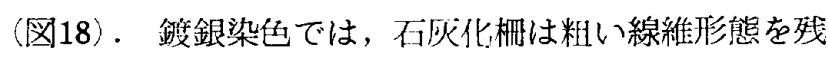
保させ赤紫色として㤠められる所もあるが，それに接し て，象牙質柵の部は黒紫色として観察される。象牙質柵

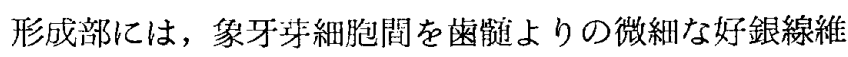
が侵入している。乙の好銀線維は，根管壁に連なる，い わゆるコルフ線維とほとんど同じ形態を示している（図 19). Elastica van Gieson 染色によると，象牙質柵 は酸性フクシンにより根管象牙質とほぼ同程度の赤色を 珰している(図20).

本例では雪髄切断部にはほとんど楽剤の牫你ならびに

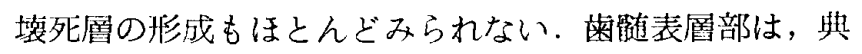
型的な象牙質柵の形成は㤠められず，獣様象牙質の形成 によりいくつかの胞陌がみられ，そこには炎症性細胞浸

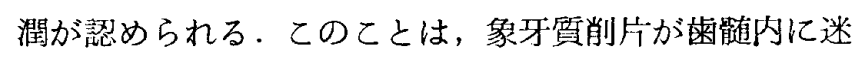
入して感染により生じたものか，楽剤のもつ刺激による ものかは明らかではない。

歯䯣切断部には，骨様象牙質と典型的な象牙質柵とが 一緒になって切断面を被覆している例である．髄腔壁側 からは象牙質柵の形成があり，中央部では骨様象牙質が 形成され，閏隙も所々に散兒されそこには歯鹃組織の侵 入もみられる。象牙質相の部には象牙第細胞は認められ るが，垨様象牙質の形成部には紡鉓形紏胞の配列がみら れる。

本例では雨髄切断面には其型的な象牙質柵の形成が諗 められる例である。それに伴って，一部象牙芽細胞も根 管の象牙第細胞と連続してほぼ嫢則正しい配列を示して いる．根尖部付近の歯䯙は線維化を起こしている．この 時期になると，von Kóssa 陽性反心忍ではすべての症例 において壇死㜿ならびに歯髄表層部には茶褐色に染まる
石灰塊あるいは一連の分界線は璆められない。このこと は，術後 1 日目に出現した不灰塊は21日目頃までは琹め られるが, その後, 融解消失したものか, あるいは象牙 賈柵の形成により減少したものかは不明である。

2 . 酸化西鉛ユージノール製剤

\section{(1) Propac}

術後 1 日

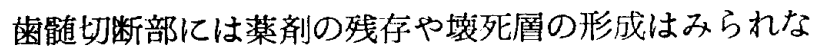
い. とくに辺縁部の茵髄においては軽度の充血, 出血が 琹められ，曾髄表層部には比較的強い細胞浸潤があり，

下層の歯髄は軽度の硝子様化を起こしている。象牙牙緗 胞層には何ら著変は認められない。

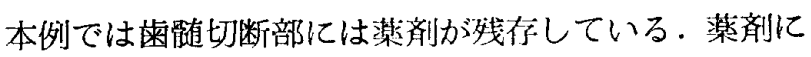
接する歯留迫切断部には一部菲薄な垻死㜿の形成が認めら れる所と，限局して強い細胞漫潤が誌められる所とがあ

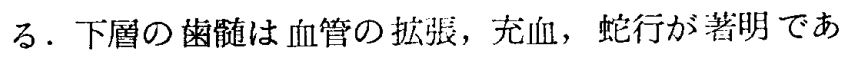
る.

菌䯙内は全体的に石灭変性が認められる他は正常像を 呈している，歯嗔切断部にはほとんど楽剂の残存はみら

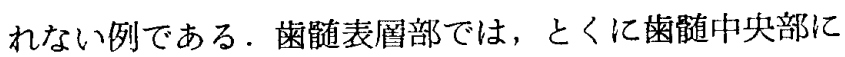
壊死層の形成がみられ，辽縁部に行くに從って韭薄にな っており柬髄細胞も諗められる。下漗の歯髄は，限局的 ではあるが充血，出血が著明で，強い細胞浸潤がある。 歯髄は全体的に正常像を保っているが，所々は不灭変性 がみられる。

術後 3 日

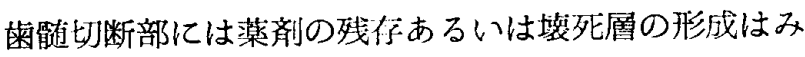

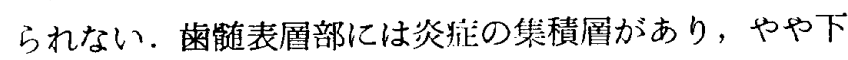

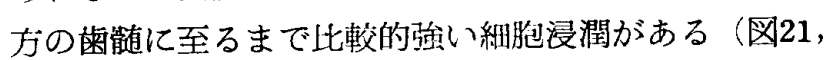
22). 鍍銀染色では, 炎症巣は濃紫色儿染色され，そこ にはほとんど翏原線維は認められないが，一部断片化し た太い線維組織がみられる. Elastica van Gieson 染 色においても同様に, 炎症巣は黄赤色を呈し, 線維組織 は一部に存在するのみではとんど㴓められない。その周 囲には淡赤色を呈した膠原線維が菌軸に平行に走ってい るのが明瞭である。

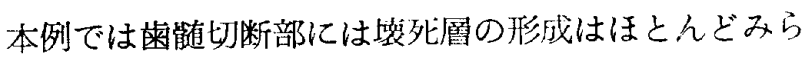
れない，鮆髄表層部は好中球を主体とする炎症の集積層 があり，膿痬を形成している。下層の菌髄の一部にも炎

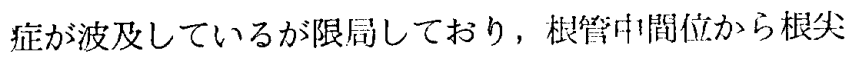

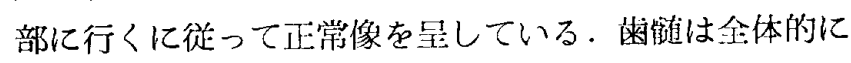
I[11管の抾張，光血が著明である。

歯髄切断部には僅かながら薬剂の残存が瑟められる例 である、薬剤に接して，とくに辺縁部において菲薄な塆 
死層の形成が認められる，歯髄中央部では，限局的であ るが強い細胞浸潤がみられ，菌髄表層部から深部にかけ て一部軽度の網㥞萎縮所見を呈している，根管中間位か ら根尖にかけての雪髄は充血調で，他は何ら著変はみら

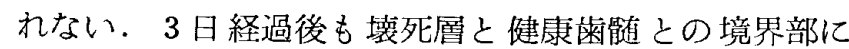
は，分界線の出現は認められない，壊死層内あるいは歯 髄表層部には，石灭顆粒は認められない。

術後 7 日

歯骾切断部には多量の薬剤の残存が認められる.薬剤

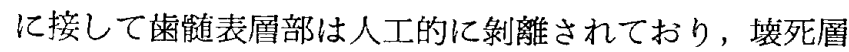
の形成はみられない，その直下の柬随には好中球，リン 八゚球を主体とする炎症性緗胞浸潤があり，その付近には 血管の拔張, 充血, 蛇行が著明である.下方に行くに従 って正常像に移行しているが，㐘䯇内には所々に石灰変 性が認められる。

本例では歯髄切断部には多量の薬剤の残存があり，薬 剂に接した䨑触組織には壊死層の形成は全く認められな いが，歯骮表層部からやや下方まで広範囲に強い炎症性 紐胞浸潤があり，膿瘍の形成も認められる．その周囲は 線維化を起ししている．下方に行くに従って正常な組織 に移行しているのが明瞭であるが，所々には石灭変性が 散見される.

歯髄切断部には広範囲にわたって薬剛が多量に認めら

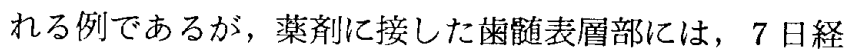
過後も分界線の出現は全く認められず，顆粒状の石灰化 物もみることはなく，軽度の炎症性細胞ならびに充血を みるのみである，歯佮通は全体的に充血調を呈している他 は何ら著変はみられない。

本例では歯䯠切断部には薬昘の残存はほとんどみられ ない，壊死層の形成も菲薄である，歯邻有表居部は，限局 性ではあるが，強い細胞浸潤が喼められる．㲽縁部にお いては，一部軽度の網様萎縮の所見を呈している．象牙

来細胞層には所々空胞変性が㤮められるが，歯邻表層 部を除いた下方の雨䈯は正常像を呈している。

術後14日

歯鹃有切断部直下には僅かに薬剤が残存している，歯艏 表曾部は，好中球を主体とした強い細胞浸潤があり，膿 陽の形成がみられ，化膿性炎症像として喼められるが限 局している．直下の歯檤組織は線維成分の豊富な所見と してみられるが，下方に行くに従ってほぼ正常な組織像 を呈している(図23，24）。鍍銀染色に上ると，炎症舁 には膠原線維はほとんぞ消失しているが，その周囲では 念珠状変性, 膨化, 断裂をなした膠原線維が乱雑に淡紫 色溻め弓れる(図25). Elastica van Gieson 染色
によると，炎症巣の周囲には細胞間を不規則に断片化し た比較的太い膠原線維が淡赤色として認められる（図 26).

本例では, 歯髄切断部には薬剤の残存や薬剤に接した

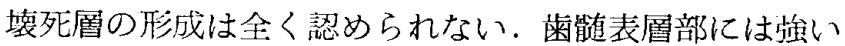
炎症性細胞の集積層があり，中央部は融解して膿瘍を形 成している所もみられる。直下の歯能通は，炎症性細胞は 軽度となり粗となっている，その下方では，ほとんぞ炎 症性細胞はなく，線維化傾向の強い所見を呈している。 根管中間位から根尖部にかけて，辺縁部から雨骮值中央部 全体にわたって線維化を起こしている。

柬髄切断部には，僅かな薬剤の残存とそれに接して菲 薄な壊死層の形成が浔められる例である，㐘䯣表層部か ら深部に向って炎症性細胞の集積層が認められ，辺縁部 では血管の充血が著明である，歯軻内部にも炎症性細胞 は諗められるが，その周囲は線維化を起てしている．根 管中間位から根尖部にかけての雪髄は根管壁にはわずか ながら歯髄細胞も認められるが，ほとんど歯髄中央部は 全体的に線維化の所見を呈しているのか明暸である。

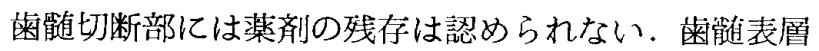
部には辺縁部から歯䯣中央部にかけて菲薄な淁死屏の形 成が琹められ，その直下には強い炎症性細胞の集積層が 広範囲にみられ，やゃ下方では菌鹃細胞が柾になってい る. 根管中間位から根尖部にかけては一部根管壁には菌 㖪細胞がみられるが, 歯髄は全体的に線維化の所見を呈 しているのが明暸である。

術後21日

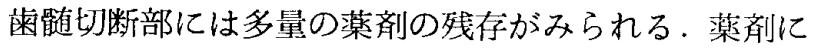

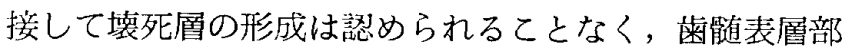
は比較的広範用に炎症性紐胞の集積層が明膫である。そ のやや下方では一部炎症の少ない幼若な肉芽組織の所見 もみられるが, 歯鹃の内部には膿㷎の形成もみられ，根 管中間位から根尖部にかけての歯根象牙質の内側は收収 され大小の山窩を形成し，そてには吸收細胞の出現が著 明に認められる。

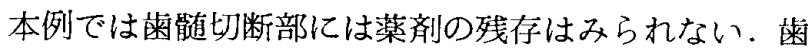
骮道表層部には強い炎症性細胞の集積層が認められる。そ のやや下方では，菌能組織は幾分柾になっておら一部硝 子様化もみられるが，根管付近の茵喠細胞を除いて全般 的に線維化傾问の強い所見を呈している。

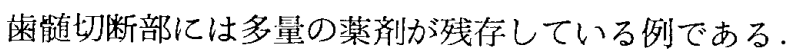
薬剂に接して，とくに辺縁部に打いては菲薄な壊死層の 形成がみられるが，歯咀道中央部に行くに従って強い炎症 性細胞があり，樑部まで広範囲に悥められる。炎聇紧の 
下方では，細胞浸潤はみられるが，線維の増殖が著明 で, 根管中間位から根尖部にかけて線維化を起てしてい るのが明暸である。

\section{術後35日}

菌髄切断部には薬剤の残存が僅かながら認められる。 菌髄表首部から内層にかけてリンパ球，好中球を主体之 する炎症性細胞の集積層が認められる．とくに辺縁部で は充血が著明であり，そこには硝子様化は認められない が，炎症巣の下方の米髄には硝子様化が起って扔り，血 管が残っている所もみられる．硝子様化している所では 石灭沈着が起っている，その下方では，軽度の細胞浸潤 は諗められるが，根管中間位から根尖部にかけては線維 が緻密になって扔り，雨髄は全体的に線維化が起ってい

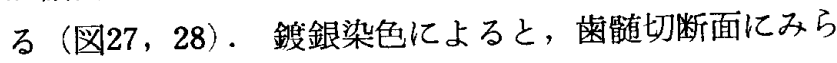
れる炎症巣は黒色または黒紫色を呈している，根管壁に 沿った部では，一部平行に走る黒紫色の粗い線維組織が 認められる．炎症巣の下方にみられる硝子様化が起って いる所は正常な線維組織は全く消失し，全体にわたって 赤紫色を呈しているが，石灰沈着の部は黒紫色に染色さ れ,そこには一部膠原線維の残存も認められる (図29).

Elastica van Gieson 染色では，切断面の炎症巣は 黄赤色を呈し，硝子様化が起っている所は淡赤色として 認められ,線維組織は全く不明崉となっている(図30)。

本例では21日目の所見とほぼ同様に曾髄表層部から樑 部にかけては広範囲に強い炎症性細胞浸潤があり，一部 では膿湯の形成も認められるが，やや下方では根管壁に

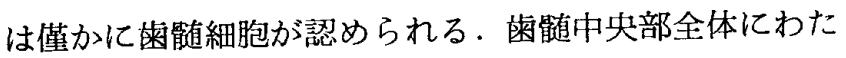
っては, 細胞浸潤は少なく線維化傾向の強い所見を呈し ている。

歯髄切断部には多量の薬剤の残存が認められる例であ

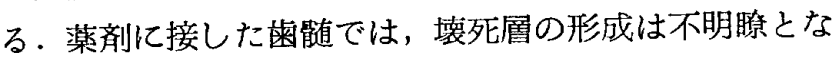
り，人工的に大きく剝離されている，菌檤表㬝部は，炎 症性細胞浸潤が強く, 辺縁部から菌髄中央部まで広範囲 に諗められる．炎症巣の下方では炎症性肉考組織の増殖 が著明であるが，根管中間位から根尖部にわたって線維 化が移行しているのが明瞭である。

術後92日

本例では曾咀切断面には薬㶡の残存は認められない。 米髄表層部には炎症性細狍浸潤が強く，一部融解して膿 嫁を形成している，歯髄内に象牙質削片が落ち込んでお り，それを核として類円形をなした数個の骨様象牙質の 形成が認められる，その周囲には，表層部からの炎症性 細胞浸潤がび漫性に認められる。下層の蒾髄は，根管壁 の一部に歯㵦細胞が認められる所もあるが, 全体的に線
維化の所見を呈している.

歯髄切断部には菲薄な壇死層の形成が認められるが， それに接する組織は一部人工的に剝離されている。それ に連続した雨髄表層部よりやや下方では，炎症性細胞の 集積層が琶められる。そて下方には，白血球，リンパ 球，プラズマ細胞などを含む炎症性肉芽組織が認められ る、また，辺縁部には幼若な肉芽組織も認められる．細 胞浸潤は下方の歯髄にまでみられるが，根管中間位より 根尖部に行くに従って線維化として想められる（図31, 32）. 鍍銀染色では，壊死層よりやや下方では黒紫色を なした炎症性細胞の集積層がある，炎症性肉牙組織の部 には, 乱雑な膠原線維が幼若な状態で出現し, 好銀性を 示している所もある。 また根管壁には, 赤紫色を呈する 膠原線維束が雪根象牙質に平行して走っているのが羿 められる(図33). Elastica van Gieson 染色による と, 鍍銀染色で黒紫色として観察される炎症巣は黄赤色 として明瞭に観察される。下方では，淡赤色を呈した幼 若な膠原線維が認められ，それは根管中間位の線維組 織と同程度の淡赤色をなした所見として認められる（図 34).

\section{(2) Topdain}

術後 1 日

歯髄切断部には薬剤の残存は認められない，切断部直 下の歯髄表層部は炎症性細胞浸潤が強く広範囲にわたつ て集積層としてみられ，膿瘍の形成も認められる．その 直下では軽度の硝子様化の所見を呈しており，その中に は細長い血管の残存も認められる。

柬髄切断部直下の表層部には限局した炎症性細胞浸潤 が琹められる例である．その直下では血管の充血が著明

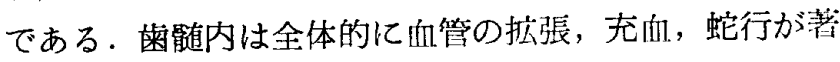
明である。

本例では曾髄切断部には薬剤の残存や壊死首の形成は ほとんどみられない，雨髄表層部からやや下方に至るま で広範囲に炎症性細胞の浸潤すなわち炎症性変化がみら れ，その直下では一部軽度の網様萎線所見を呈してい る. 根管中間位付近の歯髄内には, 石灭変性や遊離性の 象牙質粒が散見される、象牙芽細胞層には何ら著変は認 められない。

術後 3 日

菌骾表層部からやや下方に至るまで強い炎症性の細胞 浸潤がび漫性に広がっているが, 漸次, 炎症性変化は軽 度となり正常蒾髄に移行している，根管中間位よりやや 下方の菡髓には所々に石灰沈着が認められる。

歯骮有表層部には薬剤の残存や壊死層の形成は認められ 
ない例である。本例においても，㐘髄表層部は炎症性細 胞浸潤が強く，その周囲には向管の充血が著明である が，根管の下方に至ると正常像に移行しているのが明暸 である。

歯㵦切断部には薬凧の残存, 壊死層の形成は全く認め られない。切断部直下の歯髄表間部には炎症性細胞浸潤 が強く膿瘍を形成している。 その直下では，炎症はほと んどなく，肉轫組織の堌殖が著明である。一部では線維 化の様相を呈している所もみられる。鍍銀染色や Elastica van Gieson 染色では，歯髄表層部は膿焬を取 りまくように比較的太い膠原線維か淡紫色あるいは淡赤 色として明膫に琶められる。 下方に行くに従って, 幼若 な膠原線維もみられる（図35〜38）。

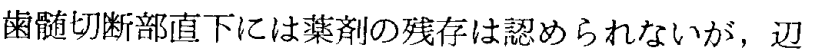
縁部で一部壊死層の形成が浔められる例である．壊死層 内には von Kóssa 陽性反忘としての石灰塊は認めら れない，歯䯙表尿部は炎症性細胞が集積して軽度の細胞 浸潤がみられるが，下方に行くに従って漸次，炎症性変 化はなくなり，雨髄全体は一般に充血調を呈し，一部に 少量の出血がみられる。

術後 7 日

歯髄切断部には分断された多量の薬郕が残存してい る、薬剤に接した辺縁部では，一部菲薄な壊死層の形成 が浔められる。菒剂に接した菌笼中央部では炎症性細胞 浸潤が認められる。その直下゙の菌髄にも炎症性変化は存

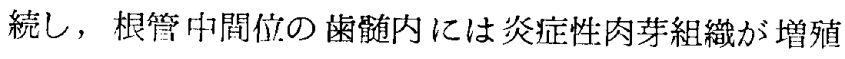
し，根管象牙䆬の内側は，限局しているが，吸収が広範 囲に認められそこには吸収紐胞が数個認められ凹窝を形 成しているのが著明である。

本列では歯霞切断部には蒌剤の残存あるいは壊死層の 形成は認められない，菌骵表層部は広範用にわたって炎 症性細胞の集積層が諗められ，膿煬の形成もある：その 值下では炎症は軽度となっているが, 柬髄内の一部には

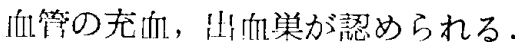

歯髄切断部には薬绪, 壊死層の形成は全くみられない 例であるが，雨躬迶表層部では充血と強い炎症性細胞浸潤 が羿められ，そこには軽度の網様萎縮所見を呈してい る、根管中間位より根父部の雨髄には, 細胞浸潤はほと んどみられないが軽度の硝子様化がみられ，そこには $2 ， 3$ 不闪沈着が琹められる。

本例では篓符表厤部からやや下方に至るまでび慢性の

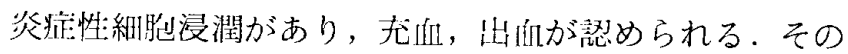

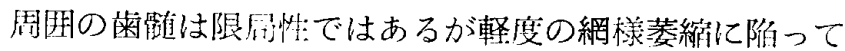
いるが，根管中閪位から根尖部に至る歯霜は漸次，健康
㐘髄に移行しているのが喼められる。

術後14日

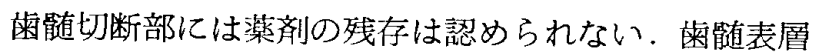
部には炎症性細胞の集積層があり，その直下には炎症性 肉芽組織が増殖しているが，辺縁部では炎症が少くなっ ており，一部では線維化の所見を呈している所もみられ る.

雬骫切断部には薬剤の残存や壊死屠の形成は認められ ない，歯髄表層部は膿瘍を形成し，膿焬内は膿球で满た されている、膿瘍の周团には被膜として線維成分に湢ん だ肉芽組織の増殖が著明である，細胞浸潤は比較的軽度

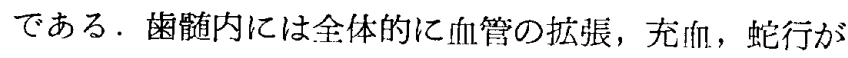
訫められ，不灰沈着や石灰化象牙質粒，化生象牙質粒な ごが散見される（図39，40)。鍍銀染色では，膿煌形成部 は黒紫色としてみられ，その周用，とくに最表層では膿 陽を取り用むようにして太い赤紫色に染色された膠原線 維が途中乱れることなく連続しているのが明瞭である. しかし，数本の翏原線維は澧瘍内に侵入して消失してい る、線維成分に富んだ肉牙組織の部には，幼若な膠原 線維が好銀性を呈している所もある(図41). Elastica van Gieson 染色によると, 膿煬の部は黄赤色に染色 され，膿瘍を取り国んでいる太い膠原線維は鍍銀染色で 諗められるように明瞭ではなく，淡赤色として明瞭に認 められる所と不明暸となっている部分がある。肉芽組織 の部分では, 幻若な膠原線維が淡赤色として認められる (羽42).

本例では切断部直下には薬剤の残存は認められない が，辺縁部において一部菲薄な壊死層の形成が熟められ る、釆髄中央部では強い炎症性細胞の浸潤があり,やゃ 下方まで琹められ，膿瘍を形成している所もみられる。 その周囲とくに根管壁側では肉芽組織の増殖が著明であ り，更に根管中間位上り下方に行く之線維化傾向の强い 所見としてみられる。

術後 $21 \Pi$

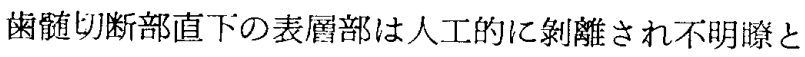
なっているが，その下方では炎症性の肉芽組織の堌殖が 著明である．根管中間位から根尖部に向って細胞浸潤は 少く，新生血管に富んだ幼若な肉牙組織の所見を呈する ようになる．象牙牙紐胞層は全体的に空胞変性，萎縮が みられる、相简壁には，部分的ではあるが，不規則な第

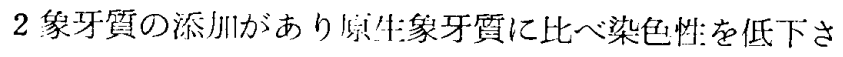

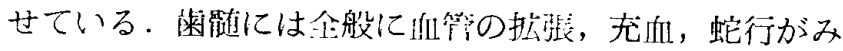

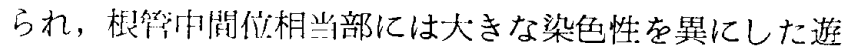
離性の象牙覧粒がみられる。 


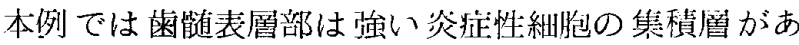

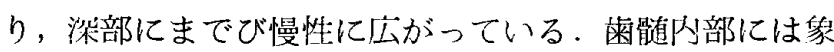
牙頻削片の迷入があり，類南組織を非成しており，その

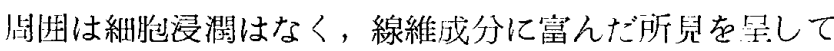
いる．少し離れた所には表層部からの細胞浸潤が連続し ているが，炎症性肉芽組織の増殖が著明である。根管中

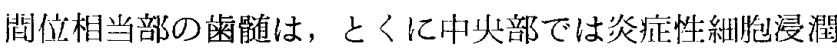
は少くなっており炎症性肉芽組織の所見を等している。 また，その部の根管壁には炎症はなく奻若な肉芽組織の 增殖が翟められるが，以测の象牙質には吸收細胞の出現 がみられ内部吸収の所見を重している。

淗髄比断部には薬剤の残存，㜔死層の坜成はみられな

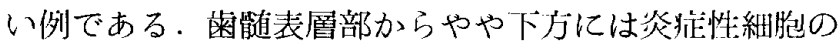

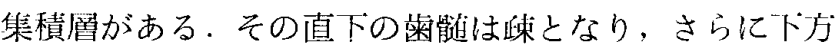
に行くと炎症性の肉芽組織の增殖が著明であるが限局し ており，漸次，細胞浸潤は軽度となり，雪能は肉第組織 に置き換り肉芽組織で渾たされているが，根管中間位か ら根尖部は線維化を呈している。根管象牙質の内側に は，不規則ではあるが，煌生象牙質に比べ染色性を低下 させた第 2 象牙質の添加が広範囲にみられる.

\section{術後35日}

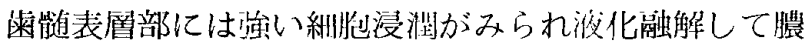

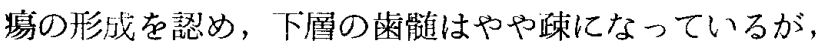
内層の歯髄は血管に富んだ奻若な肉芽組織の所見を鼠 し，歯髄は全体にわたって肉芽組織に埴き换っているの が明膫である（应 $43 ， 44$ 。镊銀染出で钼祭すると，袈 救の集積層は紫色を呈し，その下尿には黒紫色や赤紫色 として太い数個の線維束が热められる．そのド方，すな わち肉芽組織の部では, 赤紫色に一橡に染色された㬔原

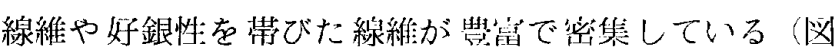
45. Elastica van Gieson 染舟によると，衣㬝部は

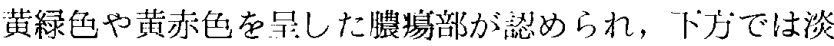
赤色をなした膠原線維が乱雑に装焦しているのがみられ 万(脳46)。

本例では表層部の紐胞浸潤は比䡈的护くなっている。

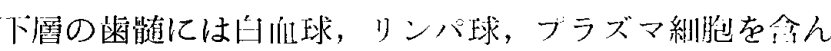
でいる资症性肉芽組織の增多通が著明であるが，下方に行 くに従って細胞浸潤は軽度となり肉牙組織の所見を! し，根管叶阔位より根尖部に向って一部線維化僋问の強 い所罗としてみられるようになる。根学壁には不規㺫な 第 2 象牙貲の添加が認められ，原生象牙賁に比へ染色性 を低下させているのが明膫である。

術後 92 日

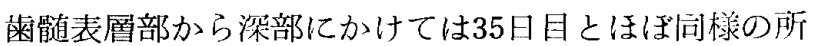

見を导しているが，下層では炎怔性肉芽組織の増殖が広 範册に羿められ根管印閏位相当部にまで達しており，下 方に行くに從って線維化としての所見を晕している.

本例では，切断部直下は炎証州:紐胞の集積層があり， 下方では炎症性の肉牙組織の堌殖が暂明である。根管中 間位あたりでは細胞浸潤は軽度で辺縁部より線維化をを! しているが，歯髄中央部付近では幼㠿な肉牙組織が認め られる．根尖部付近は全体的に線維化としての所見を荨 している.

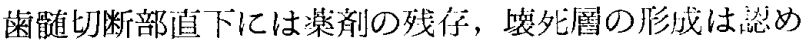
られない例であるが，雨髄内には象牙質削片が多量に散 在したものと思われ削片を核としたかなり大きな岗栐象

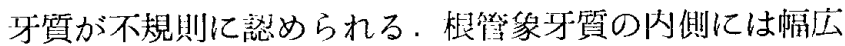

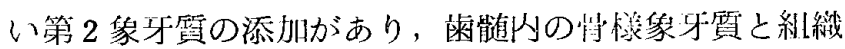
癒合が行われ歯髅を狄窄している，鋅銀染色でみると，

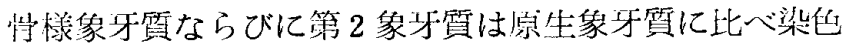
性を独くした所と低下させた所が入り鼬じっており，と くに核とした抋部が強く濃染されている。

㐘髄切断部直下には薬剤の残存や流死層の坜成は全く みられない例である，䨑髄表層部は炎将性細胞浸潤が強 く膿煌を非成している．膿陽の周囲には炎症性闪第組織 の增列所胃がみられるが，下方に行くに従って細胞浸濉 は軽度となり，血管が豊笛で肉芽組織が著明となり，曾 㭪迶全体は線維化を星している。根管壁には一部僅かに正 尝な歯髄紐胞が政見される（図47，48；

\section{総括ならびに考察}

乳来は吸收期，休比期を繰り这しながらある一定時期 になると後継永久㐘との父換現象が行われる。そのため

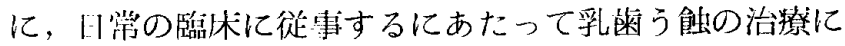

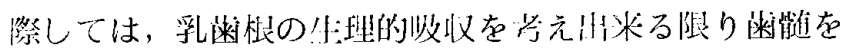

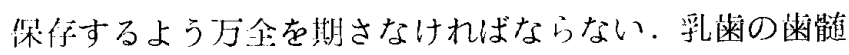

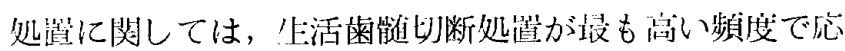

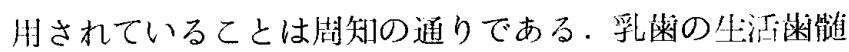

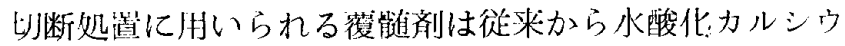

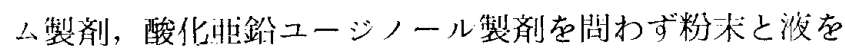
練和するものが多く日常の卧休に使用されてきた，近 年では, 楽剤の開発, 改良による進歩とともにへースト ・ペーストタイプのもの，すなわち薬羭と触媒を練和し

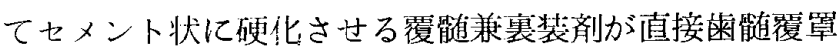
郕として，また興味あるものとして，カルボキシメチル セルローズと水酸化カルシウムが特殊の $3 \frac{1}{2}$ 入用容器に

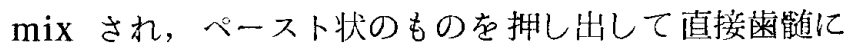
作用させる覆髄郕などが日労の臨床でむ使用されるよう 
になってきたが，それらのほとんどが教理組䄉学的には 末だ解明されていない，そこで今回，著者は乳歯の生活 菌髄切断処置に関して主に水酸化カルシウム製剤から Calcipulpe ，酸化要鉛ユージノール製剤からPropac および Topdain を選択し, 歯鹃創傷面の治療機転につ いて自験例を詳述してきたが，過去の研究者の文献を棌 猟して本研究と対比しながら考察を加えることにする。

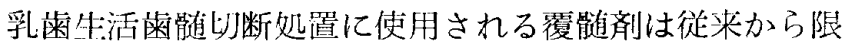
定され，とくに蕧髄兼裏装剂はう简の処置和窝洞形成を 行った場合, 粦暍を保護している象牙質の営底が菲薄に なることがあるため，象牙質を一風介して，間接的に㐘

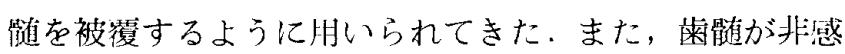

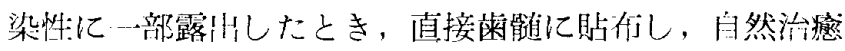
を期街して使用される場命もあった。しかし，…般的に は復能兼重装剤は象牙質を介して間接的汇使用されるも

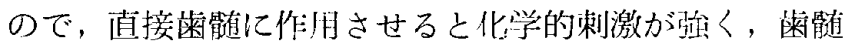

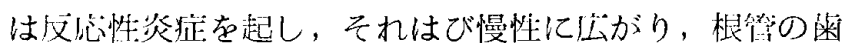
髄は化膿崩壊に陌り，霜髄の受けるダメージは大きく完 金に破烄されるものと報告されてきた。しかし，先にも

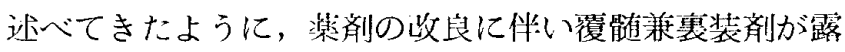
出蒌能を生物学的湾被覆保護する薬剂として広く取り人 れられるようになり，滇接画骮化忍用され，一部では坊す 理組織学的にも良い結果が報告されている。とくに乳雨

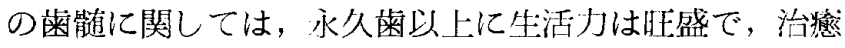
も幾分速いと報㪇されている。

最初に本矵究に用いた Calcipulpe はSeptodont Co., Paris で開発されたもので, 主成分は水酸化力ル

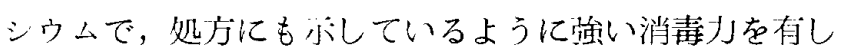
ているもので, 口腔内に怞来する酸を中和する反応を小 しており，直接来髄覆算剤として用いられているもので

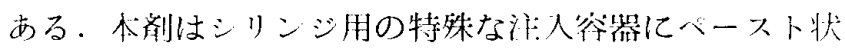

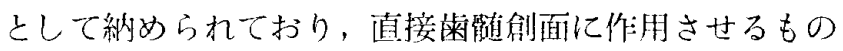
である、Calcipulpe は従米から使用されているいース

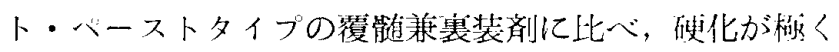
自然であり，行干羊いようであるがセメント状に硬化す

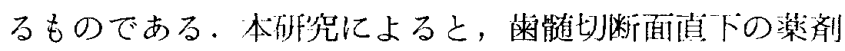

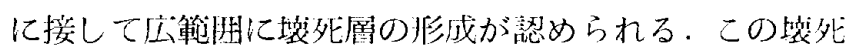
層は従来から報告されている粉末之液夕イプの水酸化力 ルシウム製剤に詡められるものと何ら変る所はみられな

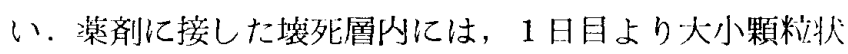
の不淡塊が連続することなく，橭々に多数散任してい る. それは hematoxylin に好染され，好塩基性を小” し, 鋖銀染色では黒色に, von Kóssa 硝酸銀法では陽 性に反応して茶褐色として明暸に誌められる。また，装

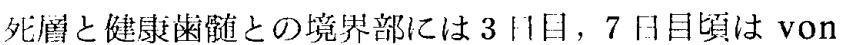
Kóssa 陽性文応居としての分界線は明睹には梽められ ない. 14 日目頃より，辺縁部から雪骾中央部に連続し て，一部密集した結晶状の顆精が von Kóssa階性仪 伈として茶褐色に染色され， hematoxylin に嶩染さ れ，鍍銀染色では琴紫色㴡色され，分界線として明膫 に悲められ，21日目には䫎も明暸之なってくる．このこ 上は過去の研究者の㐆告とは必ずしも一致していない。

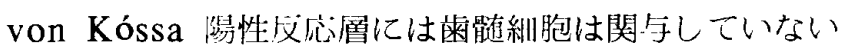
ようである。 von Kóssa 陽性父応層直トでは不闻化層 の形成があり，それに接した菌髄組織には枌化閒葉紏

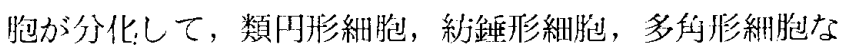

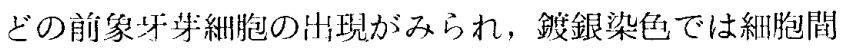
に览原線維が緙密になり, Elastica van Gieson 染他 では膠原線維が密集している，とくに，本郕は最初から ベースト状になっており，直努菌髅に作用させた場合に も日腔内温度により急激に㹬化するものでなく，自然硬 化するのが特徴的であり，幾分遅いようであるがセメン 卜状に硬化する。このことは, 組織に対する溶解性, 浸 透性も粉・液夕イブのものに比べ緩慢で, 強アルカリ性 の上うな強い刺激性者もつものではなく，組織に緩慢に 作用するものであると思われる。こてで, 戦密には壤死 層内にみられる顆粒状の不灭塊は von Kóssa 陽性反 忍層とは遊離されており区斺して考えられるべきであ

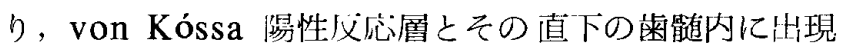
する細胞，あるいは細胞間にみられるような膠原線維も 区別されるものと思われる。

長久保 $\left(19699^{2}\right.$ は壊死首に関して特別記述していな いが，ヒトの菌牙を用いて25例中 3 例に凝固坮死層を認

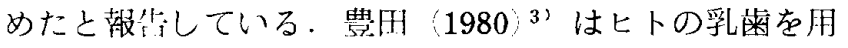
いて，闬タイフの水酸化カルシウム製郕の Procal につ

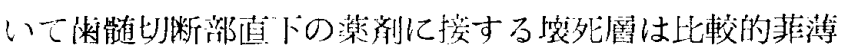

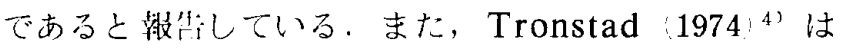

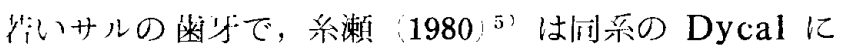

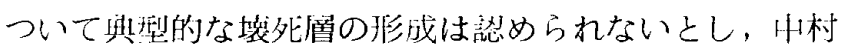

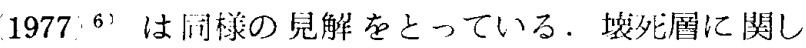

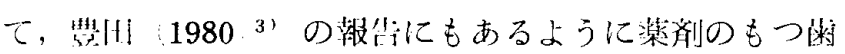

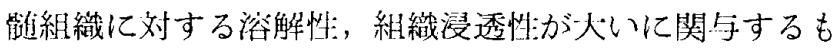
のと思われる、本研究についてみると, Calcipulpe は

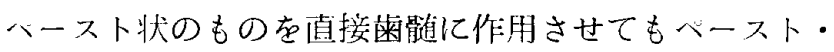
ヘーストタイフの例光ば Dycal, Procal の上うに健 化が速くなく，比較的遅いようである。術後 1 日から 92 日経過後も壊死層の組織は切断部直下の辺緣部加ら歯喵道 中央部まで広範囲汇䜑められる。䅅死層の原因について 
は, 强アルカリ性であっても弱アルカリ性であっても先 人の報告にもあるように薬郕のもつ化学的刺激であるこ とには変りない，次に㙗死層内に出現する顆粒状の不扊 塊について述べることにする，坮死層付には，大小の住 灭顆粒が 21 日目頃までは hematoxylin に好染し, 鋅 銀染色では黒紫色に, von Kóssa 陽性反応では茶褐色 に明暸に認められる。そして, 壊死層内にみられるその

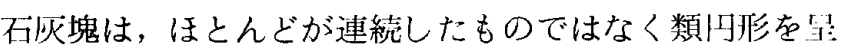
し, 個々に教在している。術後 1 日より出現し, 21 日日 にはとくにすべての弪例に其通して最も数が多く，しか も鮮明に諗められる興味ある所見を得た。このことは過 去の研究者の報告とは一致せず, 過土の呼究者は烄死層 内に認められる石灭塊は 1 日目より数を堌していると報 告している，枝(1961 ${ }^{7}$ は戊犬を用いて, 術後 1 山例 で $100 \mu$ に達する大きな顆粒の出現をみている．経日 的には, 変性, 壊死に㸝り, 次第に消失すると報答して いる。このようにいずれにしても垒死㬝内には，们灭顆 粒の存在は実証されており，丸島 $(1958)^{8)}$ は成犬を用 いて，壊死㽞内の顆精状の物質は炭酸カルシウムである ことを垫めている. 本研究についてみると, 壊死層内に 政見される顆粒状の石灭塊は, 過去の研究者が報告して いるように標本作製時に流出するものを除いて，経日的 に心ずしも消失していくものではなく生体内のカルシウ 么を活性化し, 誘発する化学的刺激が急速に働きかける 場合により異ると思われるが，いずれにしても化学的刺 激が作用している間は们死塊の山現はあると思われる。 それには歯髄内の生活才が旺盛であることが必要条件に なってくると思われる，壇死層と健康菌髄との境界部に 出現する分界線についてみると, 過去の研究者が報告し ているように分界線上には結晶状をなした顆䊀状の物質 は経日的に次第に淘集してひとつの顆料層を非成するよ うである。この顆精層はvon Kóssa 硝酸銀法で陽性 反応を示すことから燐酸カルシウムの炏着現象であるこ とは証明される。また，枝 $(1961)^{71}$ はこの燐酸力ルシ ウムの出現場所にはマグネシウムの仔任も火くことので きないものであると報告している。ここで壊北層と健牌

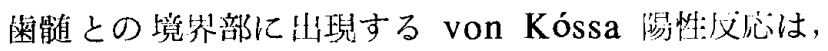
本研究では同じ水酸化カルシウム製剂を用いた場合でも 必ずしも一定時期に出現しえないことを確認した，本研 究では，1日から7日目よりむしろ14日，21日目に集中 して認められた。このととは，同じ水陵化カルシウム製 剂でも強アルカリ性のように強い制激が組織に作用した 場合は比較的早い時期に組織中のカルシウムの活性化に より誘導されるが, 本研究にみられるような組織に緩慢
に作用する場合はカルシウム，その他無機壏類などの沈 着も遅れるものと推察される。また，本所究に関する限

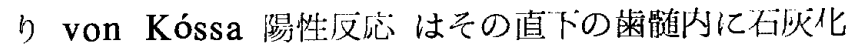
柈抢成時期に最も著明に兒われている。

von Kóssa 陽性反応層としての分界線は, 此較的典 型的な装死層，象牙質柵が形成された所見では明睹に諗

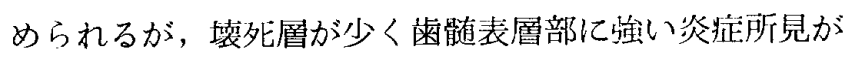

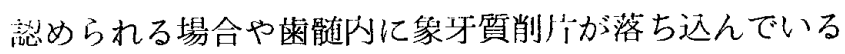
場合は全くみられないか不明膫となーててい場合が多い ようである。

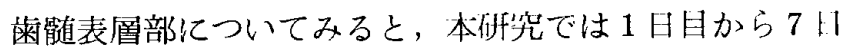
目頃までは伩応性炎症として限局した軽度の炎症性細胞 浸潤が珰められ，鍍銀染色では淡赤紫色に，Elastica van Gieson 染色では黄赤色に染色され，線維組織は ほとんどみられないが念珠状変性や断片化した線維組織 が一部散見される。長久保 $(1969)^{2}$ はヒトの米牙を用 いて Calcipulpe を直接柬葡に覆罩し，その效果に関 して臨休病理学的に報告している.それによると, 病理 成績では25例中19例（76\%）良好あるいは概良で，6例

$(24 \%)$ 不良であったと報告している，本矿究でみられ るような経日的な観察ではないが, 術後 4 日目は不良例 で，根部歯髄まで凝固壊死層を認め，10日，11日目は雪

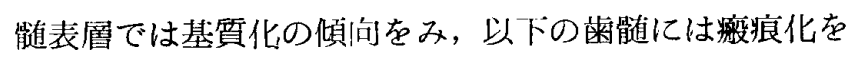

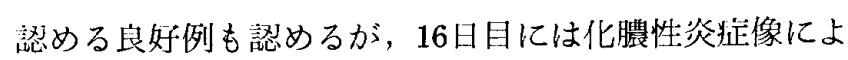
り不良であったと報告している。糸瀬（1980） ${ }^{5)}$ は同し 水酸化カルシウム製剤のペーストタイプの Dycal を用 い, ヒトの乳蒾に生活歯践切断を施し, 坊理組織学的所 見を述べている。それによると, 術後 3 日目では雪髄表 層部には硝子橡変性をみ，7日例では好中球，リンパ 球，プラズマ絒胞を主体とした中等度の炎怔性細胞を認 め，14月目に至ると似化の所罗をみている。豊击（19 $80{ }^{3 \prime}$ は夙しくくProcal を用いて，1日，3日目には荬

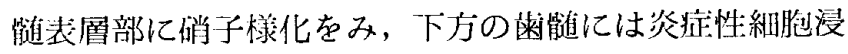
門在声し，7日経過例においても表層部はリンバ球，好 酸球が多く，好中球の少ない炎症性紐胞浸潤の所見を み，14日経過例についても似化の所見はみられないと 報留している。

ここで粉末と液からなる覆能偊について記述してみる 之, 枝 $(1961)^{7)}$ は成犬の雨牙で水睃化カルシウム滅菌 バスタを用いて，菌髄内に打ける然験的硬組織の形成に 関して組織化学的な観察を行い, von Kóssa 陽性圏は 術後 3 時間例で認められ, hematoxylin に染色される ようになると報告している，そして 5 日目には大型の細 胞の集合がみられ，Elastica van Gieson 染色で膠原 


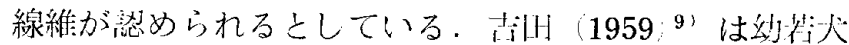
の宷牙で牛活㕣䯣切断術を行い水酸化力ルシウム蒸留水

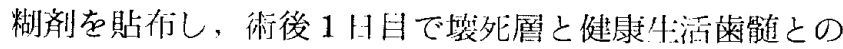
筧界部に von Kóssa 陽性:顆粓層としての分界線の出 現をみている。7日目には象牙牙紐胞漛の紐胞群の配列

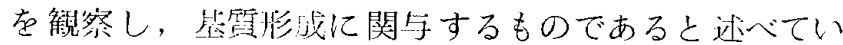

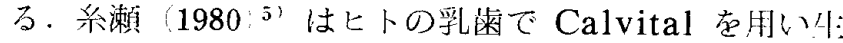

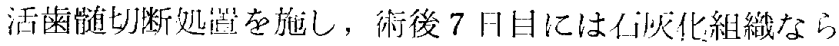

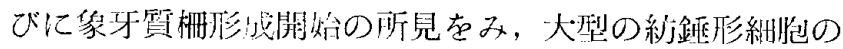

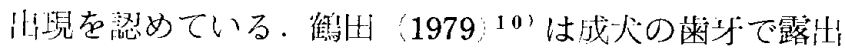

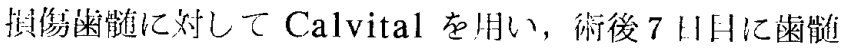

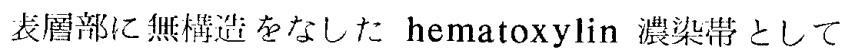

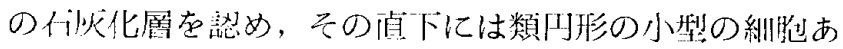

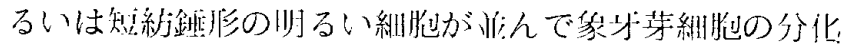

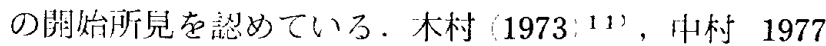

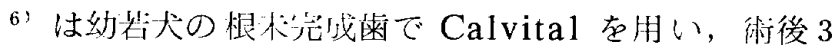

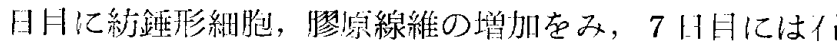
灭化組織ならびに象牙質䒽形成開始の所見をみている。 このように同じ水峻化カルシウム製剂でも本砋究や少人 の報符にもあるように，バーストタイプのものは，一般

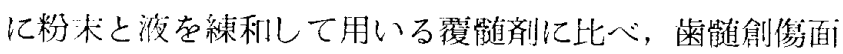
の治獠は逢いことが实恠される。

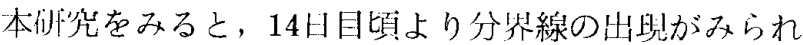
るが，21日経過すると14日目に比べ分界線は一層明膫と なり,鈙銀染色では淡赤紫色に, Elastica van Gieson

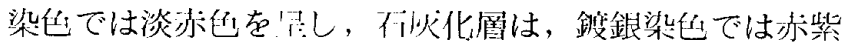
乣に, Elastica van Gieson 染出では赩に染色さ

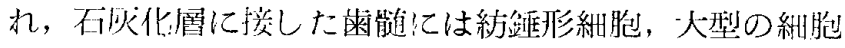

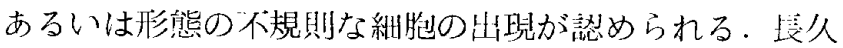

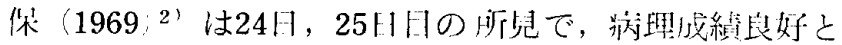

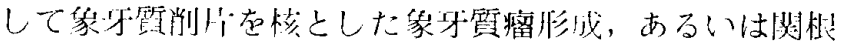

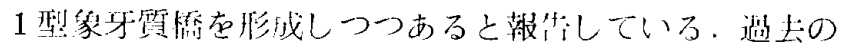

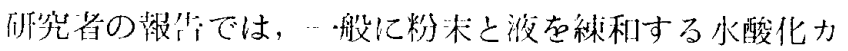

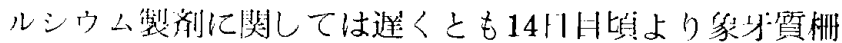

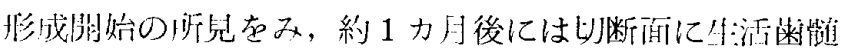
を保護する破組織の媇成が涊められるようである。本们

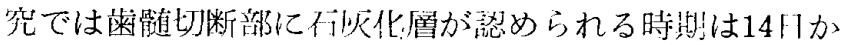
ら21日目頃であり，蒙牙質相の形成は35日から92日頃で ある、ただし，35日目と92日目の所見において，一部炎 轿が残っている例专愁められる事から，不安定な状態に あり，すべての㱑例において典型的な象牙質柵の形成を 期待することは非常に困難であると推察される。欴久保

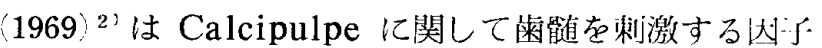
として糊剂帆令有された非吸収玳物質が原四であると
竍告しており，とくに98日から580日の坟期間例におい

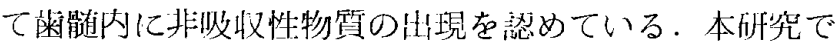
は，最垃 92 日経過例の所見において北吸收性の物質は愁 めるととはできなかったが，Calciplupe の成分川に令 有されている硫酸バりウムが，蔳者が今までにみた楽剂 の処方中の制命に比数してかなり多く弇有されているこ

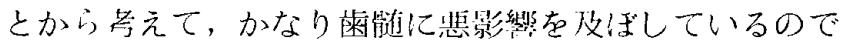
はないかと推察される。

PropacはZinc oxide Eugenol 存主成分よする㠅

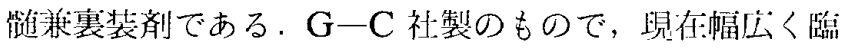
休で使朋されているものである.Zinc oxide paste と

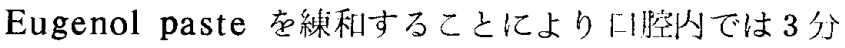

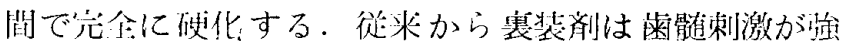

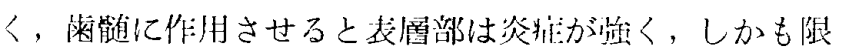

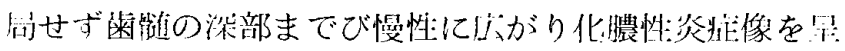

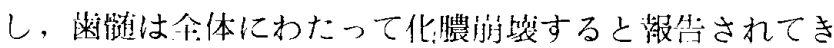

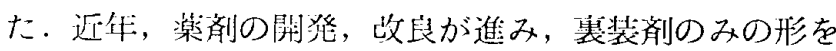

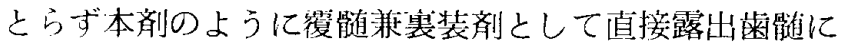
作拥させても臨床的に何ら支障をきたさないものとして 広籁囲に灾用されているが, 病理組織学的検染はなされ

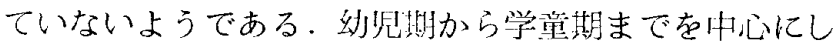

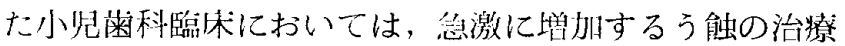
に際して粐化象牙質を残さず笔全江除去する段階で象牙: 質が韭薄となり，一酋を介することなく，任とんど雨髉 を露出する埸合があり，永久充填における維持を求める

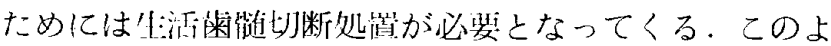

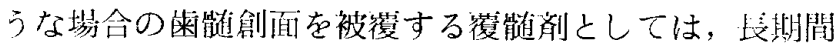
健化しないものに比へ，四腙内ですみやかに，且つ，速

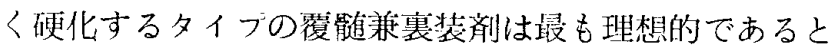
琹われる。臨休的には目的支迸成できるとしても，病理

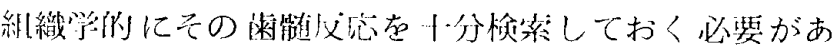
る.

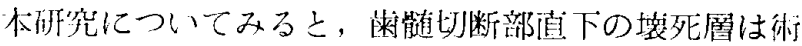

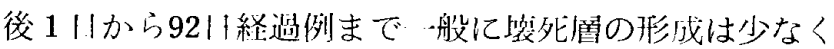

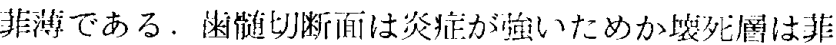

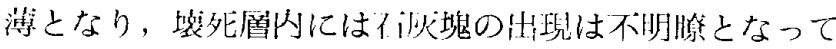

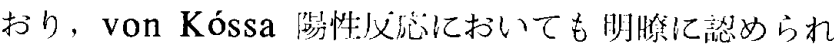

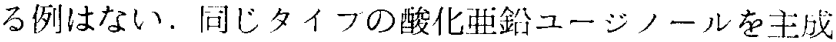
分とした Cavitec の例について，鹤田（1979１0）は壊 死層の形成はみているが具型的な坮死層ではなく，とき には流死層と炎聇性䋖胞浸潤が混在していると報告して

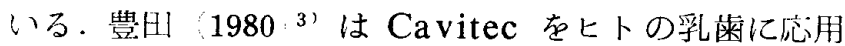

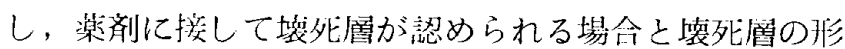
成はなく，直接菌铕表層部に炎症性紐胞の集積層がある 
場合とがあると述べている。豊开 $(1980)^{32}$ は中村 19

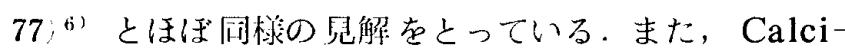
pulpe の例にみられるような壊死層と健康歯䯣との境 界部に出現する von Kóssa 陽性文志を示す風はPropac の例ではすべての症例において認めることは出来

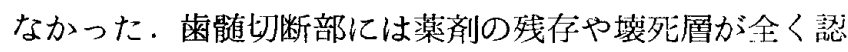
められることなく，菌髄表層部では強い炎症性細胞浸潤

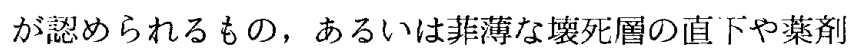

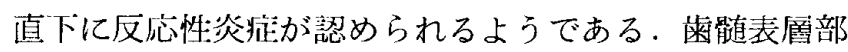
についてみると，本研究では 1 日から 7 日目頃までは立 血, 出血があり, 比較的強い紼胞浸潤があり, 膿缶の形 成が悲められる例もある。 Magnusson（1971〉12）は 乳菌38本について同タイプの酸化要鉛ユージノール糊戍 を用い観察し，臨床的には何ら症状はみられないとして いるが，病理組織学的に全症例について内部吸収を琶め

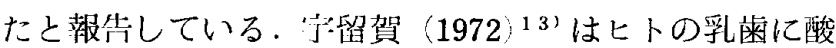
化垔鉛ユージノールを主成分とする粉末と淮を練和して 用いる Neodyne について臨床荫理学的に報尖してい る。それによると，1日から7日目の所見については一 般に充血，出血，炎症性細胞浸潤老悲め，ときとして液 死，化膿性炎症像喼めている。 Quigley $(1956)^{14}$ 'は 酸化画鉛ユージノール糊剤で16匹の八ムスタ一の菌牙を 用い，直接歯髄に覆罩し，14日目までの所見では主とし て急性炎症を啚し，膿煌の形成も瑟められるが線維化の 所見もみている.また, Glass and Zander (1949) ${ }^{15}$ ) はヒトの小四菌を用いて実験を行い，直接柬髄に覆罩す ると治療は起らず慢性炎症を旺すると報告している，本 研究では, 術後14日目頃より歯髄表層部は今だ䖯い炎症: 性細胞浸潤を瑟めているが，深部に行くに従って炎証が 少なくなり線維化を苹するようになり，鋅銀染色あるい は Elastica van Gieson 染色においても淡紫色また は淡赤色者昌しており明嘹となっており，92日において もなお継続している所見がみられる。しかし，なかには 21日例の上うに内部吸収が㲔められ，そこには吸収細胞

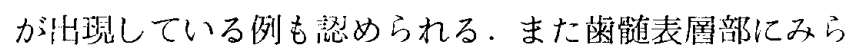
れる诎い炎症性:維胞の集棈原は92日経過例についてもす べての所兒に潖められ，炎缽の一一凰として消失すること なく継続しているようであるが，下方の菓髄に移行する に従って線維成分が豊富になり肉芽組織の增殖がみら

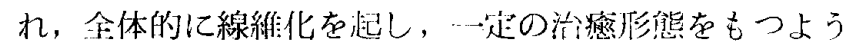
である。

本研究に関する限り，92日目までの所見の範国で Massler, et al. (1955) 16) が報去しているような露纤

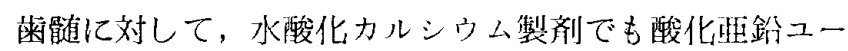

ジノール製剤でも治療の基本的形熊は同一であるとの報

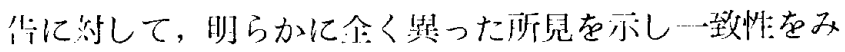
ない.また, Berman and Massler (1958) 17) はラッ 卜の雨牙を用い，水酸化カルシウム製剤抢よび酸化雨釗 ユージノール製剤で直接菌髄を覆罩し病理組織学的検索 の絬果, 西者は治癒形態はほぼ同じであるが, 水酸化力 ルシウムが治瘾の点で優れていると述べ，しかも術後 21 月，28日経過後は両者とも治癒形態は類似していると報

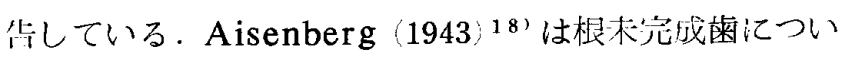
て象牙質橋の形成を覟めている，著者はこの点について 少し咩紼に述べるとにする.Propac の例では，すべ

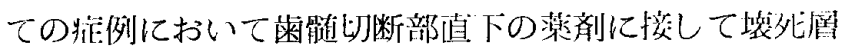
の形成は非常に少なく，垻死層と健康菌噵との境界部に は分界線の出現はなく, von Kóssa 陽性反応においても 明らかに直接強い炎症性紐胞の集積畨が㤠められた。象 可質削片が米髉内に落ち込んだ場合, 料骮表層部から曾

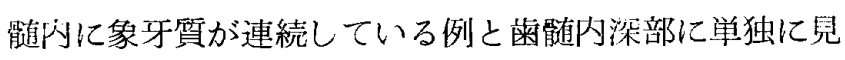
られる例とがある，前者の場命は比断部には比較的大き

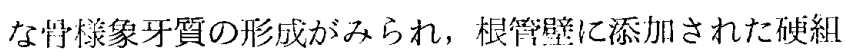
織と組織療合が行われる場合がある。しかし，乙の場合 は必ず歯髄組織を介在させており，薬敦による反忍とし

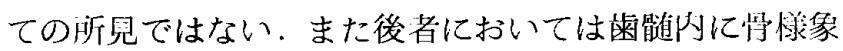
牙質の形成はみられるが，㐘髄切断部を被覆するまでに は至らないのがほとんどである。战椂象牙質の周囲には 非象牙芽紐胞㥞のものはみることはあっても，象牙牙細 胞はみるととはなく，また，線維芽細胞の出現があり線 維成分に富んだ所芫としてみられる例もある。骨様象牙

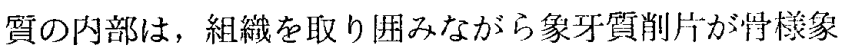
牙質を形成して行くものと思われ，紐胞を封入し，血敒:

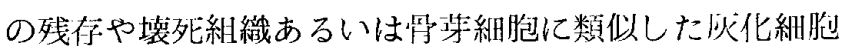
の残存などがみられ，监型的な像牙細管をもつ硬組織の 嫄成をとらないで，なかには粗い網目状をなしたものも あり，外界との交通がみられる例がほとんどである。

次に㭼郕が雨骮阿に埋入した例では，その周囲は炎症。

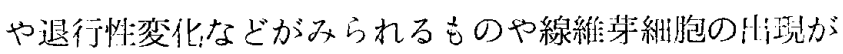
みられる例がある。また，葙剤と象牙質削片が混合して

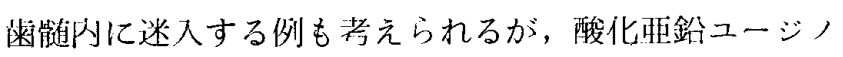
一ル製剤に関しては象牙質柵の形成は考えられない，水 酸化カルシウム製剂に関しては, 藻剤周囲に膠原線維が 集命し，イ伙化組織の㹉態はとっても象牙:質柵の情暹は とらないものと思われる．本研觉においても一部の例で 認めているように，過去の研究者のなか汇は象牙翼削片 在核として形成された骨様象牙質も梖郕の反忘に上る缏

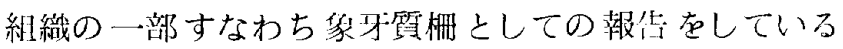




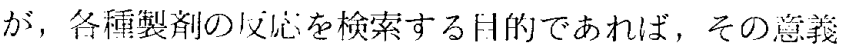
は食くなく除外すべきである。なぜならば，象牙質削り

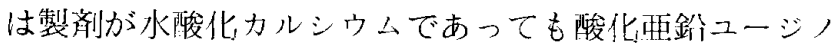
ール製郕，ホルモクレゾール製戍であっても画随內に

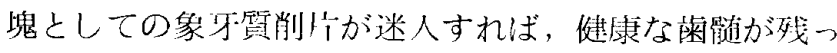
てしかも特活が昨盛であれば大小の相違はあっても

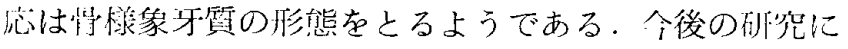

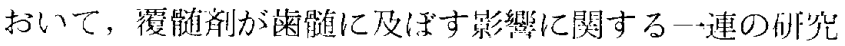
は，象牙質削勀関与して䚲成された硬組織は檪剂と組

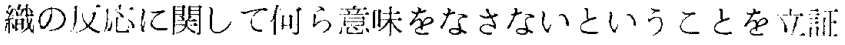
しており，乙の点は人いに湆朋される些である。Zan

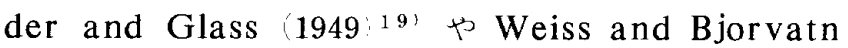

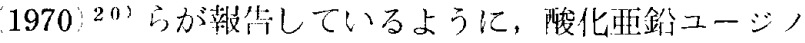

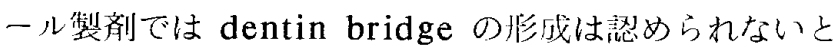

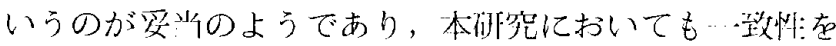
みる。

Topdain は Showa Yakuhin Kako Co. 斟で,

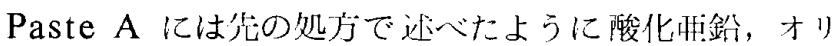

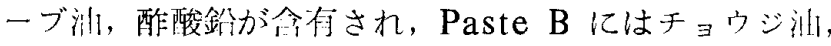
ロジンが合有されている。この䧋者を練和して使用す

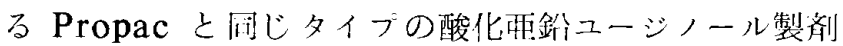

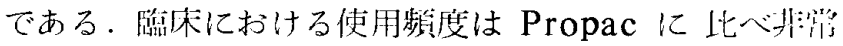

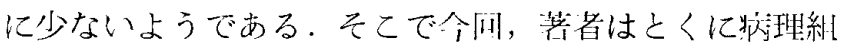
織学啲に Topdain が歯歫道にどのような作用を六すも のか, またPropac に比べ治癒機転には养があるのか ごうかを検討するために選把したわけである。菌科医兴

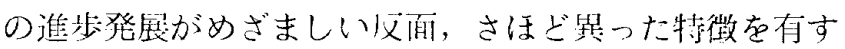

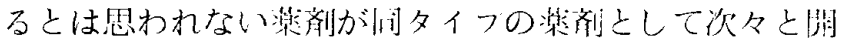

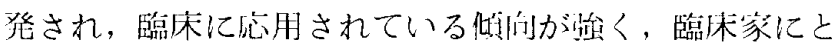
ってはどのような薬剤を使用してよいものか氿定し難い こともしばしばであると思われる。このように，闹タイ

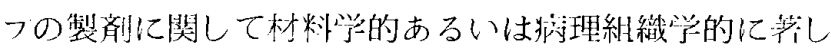

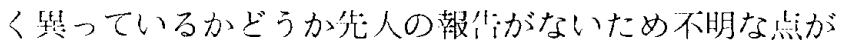

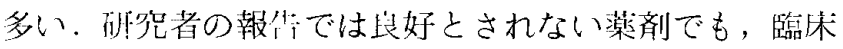

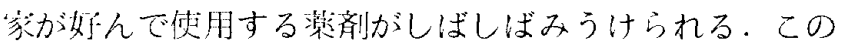

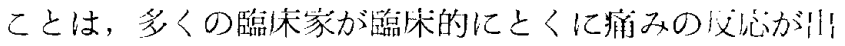
䠐しなければケ後良好とみなし，優れたものであり，优 い易いものであるという安易な考えを今だにもっている

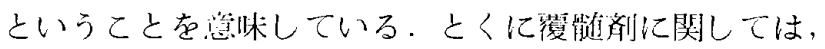
川貶されている桨剤は多いようであり，それらの兴剂の 铰密な痛理組織学的な裏付けが急がれる。

本矿究ではあくまでも病理組織学的檢索のみによる韩 行を行っているが，他方では Englander, et al. 19

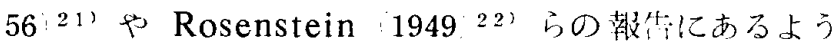

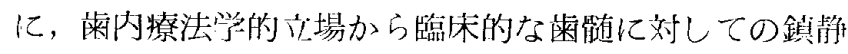

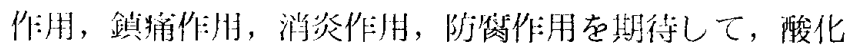

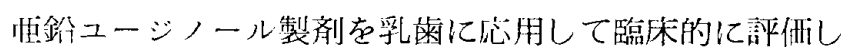
ている。水酸化力ルシウム製剤，ホルモクレゾール製剂

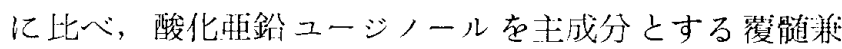
裹裴用は今後も大なる比雨を占めるものと思われる.

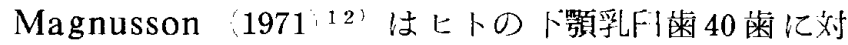

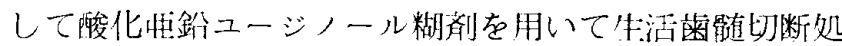

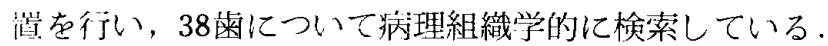
それによると, すべての㐘牙に炎症症状を闪, 治癒し

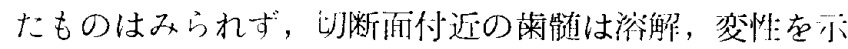

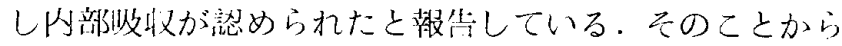
しても坊理組織学的検索を十分行って隐休に灾用するな らば，さらに臨床家の期街にそえるものと思われる。本

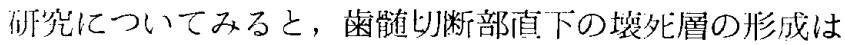
Propac の例に比べさらに少ないよらである，壊死層内

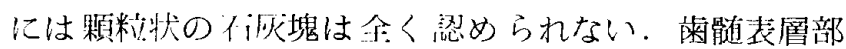
は，炎怔州:紏胞の集積層がみられ膿陽を玥成している所

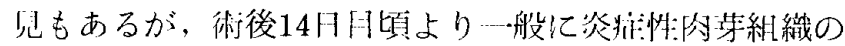

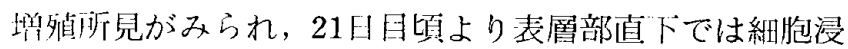
泪は比較的軽度となり線維成分に雷んだ肉芽組織の刻列!

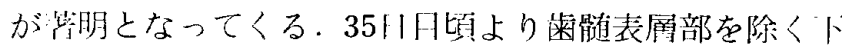

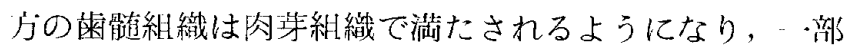
では線維化倾间の強い所見がみられるようになり，921 に系ってもそれが継続しているようである。このこと

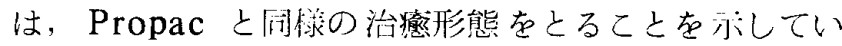
る。また本例でもみられるように，一般に象牙質削片が

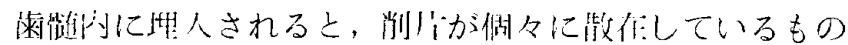

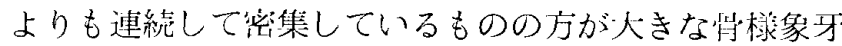
質を非成しているようである。省栐象牙質の队部には削 けが核となったことを琶距するいくつかの削版 he

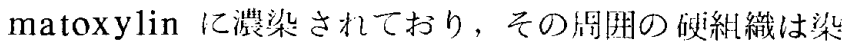
色性:を低卜させているのが明膫である。そして先人の敬 行にあるように，あたかも水酸化カルシウム製阁も酸

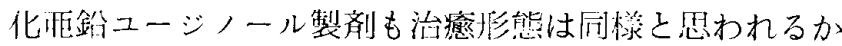

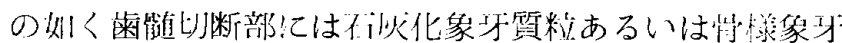
医の非成が垫められる場命があるが，活とんどが組織を

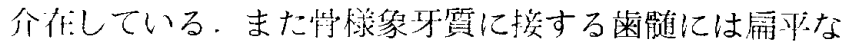

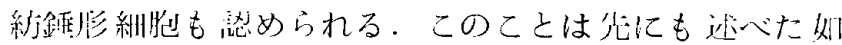

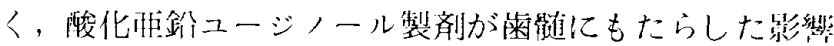

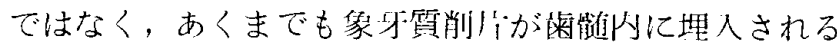
とこのような不規剘な硬組織の修成がみられるもので，

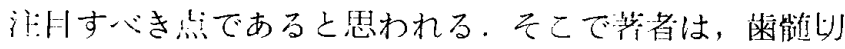

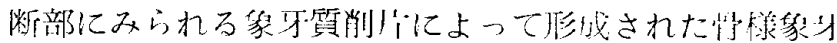


質は薬剤による作用ではなく们ら治癒の対象にはならな いものとして今後の研究に付加しておきたい，関根（19

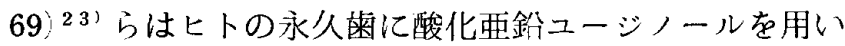
生活爽髄切断法を行い，13例 $(44.4 \%$ ）江象牙質障壁の 形成を珰めているが，ての象牙質障壁は手術後に坦入さ れた象牙質削片を核として形成された象牙質䊀が相互に 癒着して形成されたものと考えている。

Propac や Topdain に関しては，吉間（1969) 24) が生活米能切断処置について報告しているように，臨林 的には冠部霜髄が感染の嶷いがある場合には感染部を徹 底的に除去する必要がある．現在臨休で使用されている

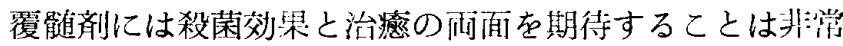
に困難である．各種严鉛華ユージノール製刘に関して殺 菌效果について報告しているものとして, 服部ら (1961) 25) は供試菌として Aerobacter odontolysogenes $\left(\mathrm{N}_{2}\right.$ 株), Staphylococcus aureus (209 P 株), Escherichichia coli (E. coli), Candida albicans, Candida krausei を用い，ユージノ一ルは殺藏力が少っていると 述心，創面からの污染物の侵入を考えた浸透試験の絬果 もよくないと報告している。乙のように殺菌効果を期街 し，しかも苗髄に対して便組織により治痖する理想的な

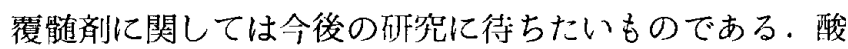
化要鉛ユージノール製剂に関しては，吉时 (1969)24)が 報告しているように生活菌髄切断処置の適忘症として は，乳歯，永久苗を問わず，健康歯髄，急性一部性漿液 性菌髄炎の初期で炎症が喠角の一部に限局している場

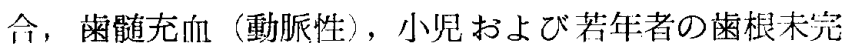
成菌などが挙げられ，臨床的にも湖街できるものと思わ れる. 浅井ら $(1969)^{26}$ は比の歯牙を用いて，とくに 幼若永久歯に酸化亜鉛ユージノール糊剤を作用させて健

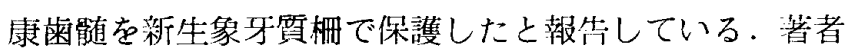
が用いたPropac や Topdain の例では, 象牙質棚の

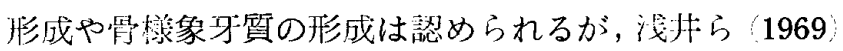
26) の報告とは一致性をみない. Propac や Topdain

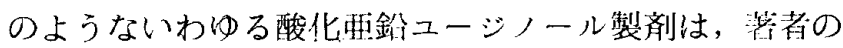
研究に関する限り垻死層の形成をほとんどみることはな く, 琶められるとしても菲薄で炎症性変化を惹起するの が速い．しかも術後 1 日から長期間の92日例まで炎症性: 変化を琹め，分界線は出現しないまま経過する。ただ， 時に象牙質削片が歯喠内に埋入し未分化間葉細胞を適度 に刺激すると，象牙質粒や骨栐象牙質が形成されるもの と思われる。乙のことから，浅井ら $(1969)^{26}{ }^{6}$ が報告し ていることは典型的な象牙質栅の形成ではないと思われ る、このように本研究では酸化垔鈆ユージノ一ル製郕に
関してはすべての症例に分界線の出現はなく，また分界 線のH現がない場合は硬組織形成はありえないことを小゙ 唆したものとして興味をひくものである．また，酸化雨

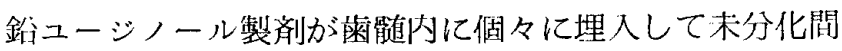
葉細胞を刺激することにより，その細胞を象牙質梱を形 成する細胞仁分化させうるか否かは本研究では確認でき ない，しかし，消様象牙質周囲に形態の不規则な紼胞が 㸡見されることがあるということは確舁である。

次に乳霜生活歯䯣切断後の内部吸収についてみると, 水婹化カルシウム製剤, 酸化垔鈶ユージノール製剤, そ してへ回の藷者の報器ははないホルモクレゾール製剤に 関して队部眨收を悲めたという矿究者の報少がある。本 研究では, Propac の例では21日目, Topdain の例で は7 日目,21日目に内部吸収の所見をみている.Propac の例では，内部吸収を惹起している部には炎证:性紐胞浸 澗はほとんぞなく幼若な因芽組織の所見を呈している。

Topdainの例では, 炎症性肉芽組織に連続して队部吸 収の所兒が琹められる.内部吸収の部では根管象牙質の 内側に大小の凹窝を形成し，吸収紏胞の出現が著明であ る. 系瀬 $(1980)^{5}$ 'は上卜の乳菌支使用して, ホルモク レゾール製剤による生活菊䯣切断処置後35日目に内部扱 収の所見㤵めている. Magnusson (1971) 12) は先に

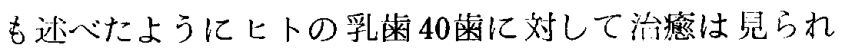
ず変性や内部吸収をみたと報告している，また Glass and Zander (1949) 15’は9 歳から15歳までの小罗患者 の便宜拔去菌牙で，之くに健康な永久小曰橉を用い，酸 化要鈶ユージノ一ル糊剤による直接歯髄覆罩実験を行

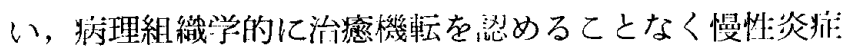
が溻められたと報告している。本破究では, 術後 1 日か ら92日経過例まで匊能有表層部に強い炎症性細胞浸潤が認

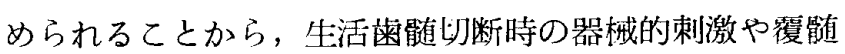
郕のもつ㺈い刺激が菌髄組織に加わり，知期間で消失す ることなく慢性的な刺激として長期間雨䯣に炎症が持続 し，その結果，歯能俌が肉芽組織に変化するものと思われ る。刉部吸収を惹起している所見においても，すでに炎

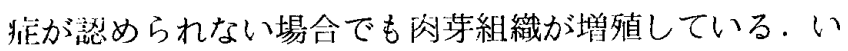
ずれにしても，薬剤の刺激により歯葡組織は強い変化を

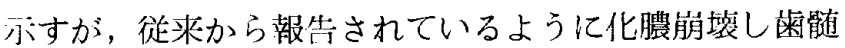
組織全体が破鍡されるような大きな名メージはみられな い.ここで日常の臨床に使用されている酸化事鉛ユージ ノール京成分とする製凨についてみると，一般に酸化 要鉛ユージノ一ル製郕は, ュージノールの水酸基と亜鈆 が配位結合してキレートを作るため，日管の臨休で使用 されている酸化亜鉛ユージノールを主成分とする覆髄剂 


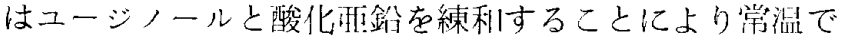

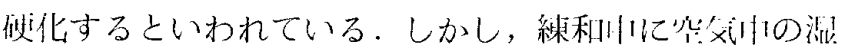
欷などにはとくに注意を払わないと，水分子が加わると

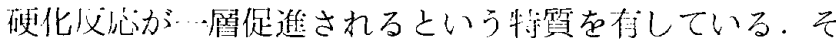

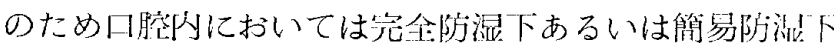

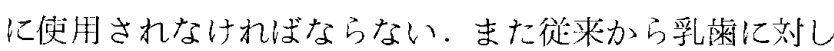
て好んで用いられている理由としては，ュージノールは 膇能炎などによる疼痛に対して鎮痛作用を付しており，

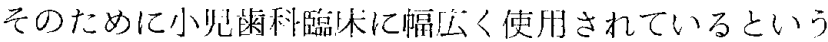
䦌知の再导と，さらにもうひとつの理由としてューシ，

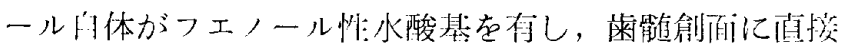

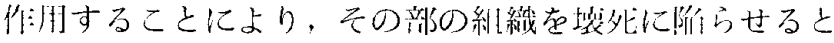

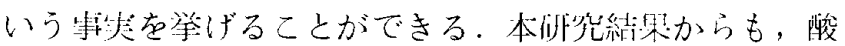
化非銓ニージノール製剂は強い刺激性を得しているとい

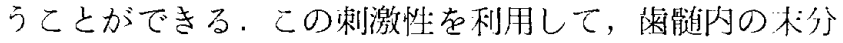

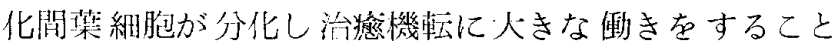
は，本砄觉の Propac あるいは Topdain の例でも怣 める糹である。

\section{結 論}

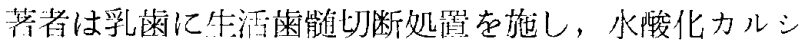

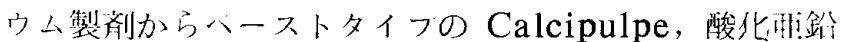
ユージノール製剤からベースト夕イプ Propac およ

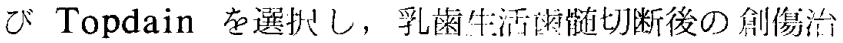

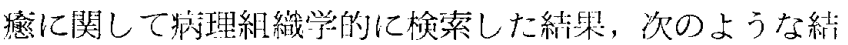
䜽在得た。

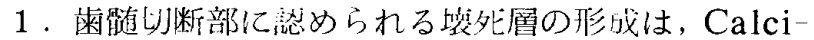
pulpe の例では比較的広範四で，Propac 拈よご To-

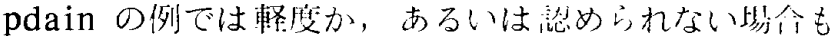
ある。

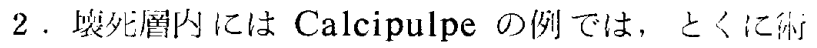

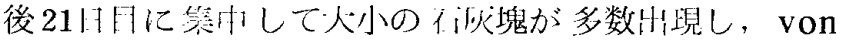

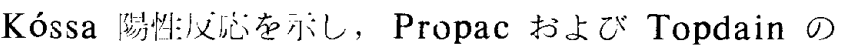

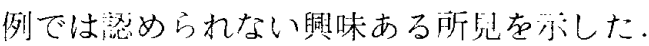

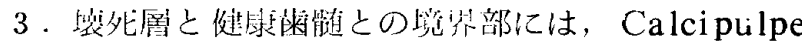

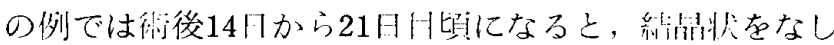

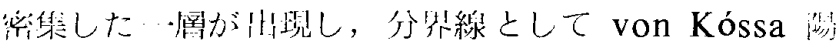

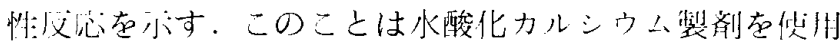

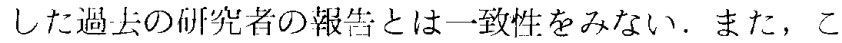

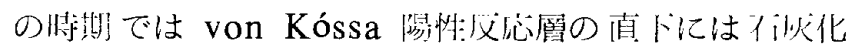

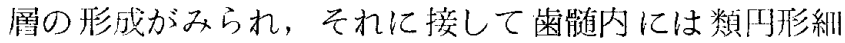

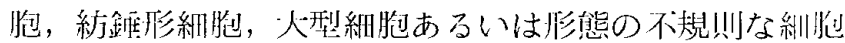

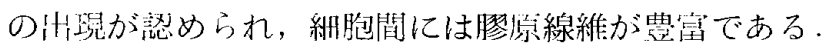

4.酸化平鈖 ユージノール製剤であるPropac およ び Topdainの例では分界線の出垷はなく，炎症性:細胞 の集積㬝があり，膿煬の形成が琹められる例もあるが， 線維成分に富んだ闪第組織の增列が著明となり，下广に 行くに徒って線維化の所見を暑するようになる。乙のよ うに分界線の州思がない場命は硬紞織非成はあり市ない ことを小惨している。

5.921子経過すると,Calcipulpe の侧では憀原線維 性些丝としての粗い不伙化柵が，敛銀染出あるいは

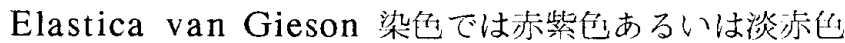

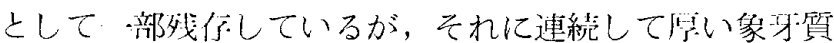
棚の非成が恐められる。象牙質柵嵃成部には㐘骮よりの 妒銀線維が進人している讪もみられる。この好銀線維は

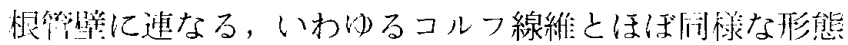
を小している。 Propac および Topdain の例では， 14 「から21月月頃よりみられた線維化の状態が92月経過 後も継続している。

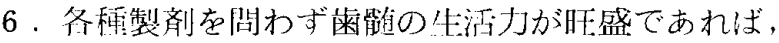

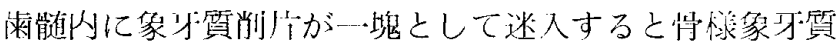
の形態をとる。このことは薂剤の作用によって形成され たものでなく今後の一速の砸究に小唆を与える注Hす心゙ き点である。

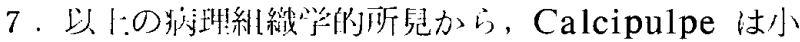

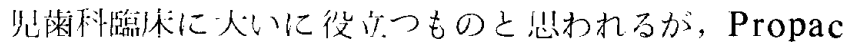
および Topdain の例ではその效梨が仿安走な状䐅に ある。

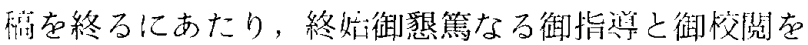

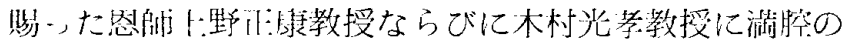

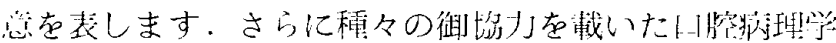

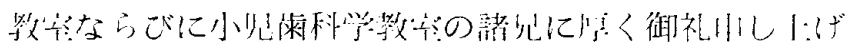
る次第です。

\section{引用 文 献}

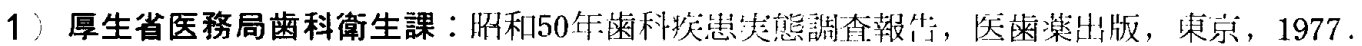

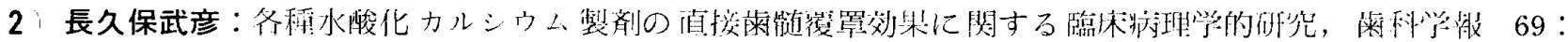
$104-161 ， 1969$. 


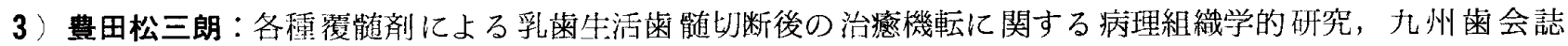
$34: 129-155,1980$.

4 ) Tronstad, L. : Reaction of the exposed pulp to Dycal treatment, Oral Surg . 38:945-953, 1974 .

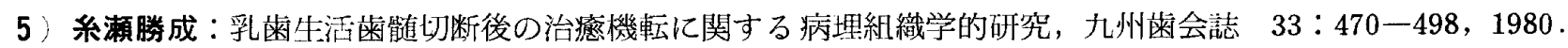

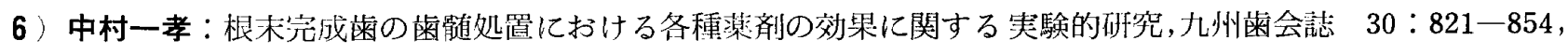
1977 .

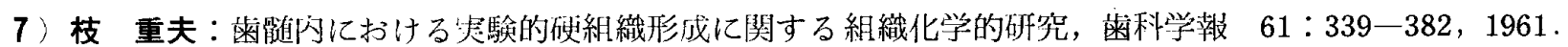

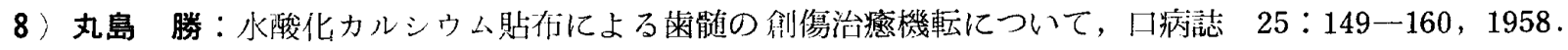

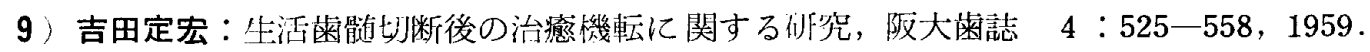

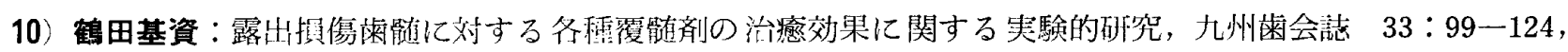
1979.

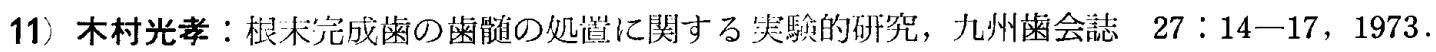

12) Magnusson, B.: Therapentic pulpotomy in primary molars, clinical and histological follow-up, II. Zinc oxide-eugenol as wound dressing, Odont. Revy. 22:45-54, 1971.

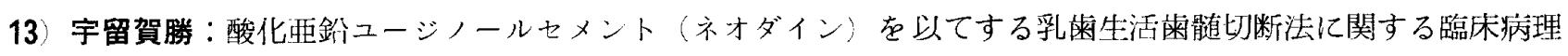
学的矿究, 雪科学教 $72: 113-147,1972$.

14) Quigley, M. B. : Experimental exposure of hamster pulp, Oral Surg. 9:1124-1131, 1956.

15) Glass, R. L. and Zander, H. A. : Pulphealing, J. Dent. Res. 28:97-107, 1949.

16) Massler, M., Perreault, J. G., et al.: Experimental pulpotomy in incisors of the rat, J. Dent. Res. $34: 711-712,1955$.

17) Berman, D. S. and Massler, M. Experimental pulpotomies in rat molart, J. Dent Res. $37: 229-242,1958$.

18) Aisenberg, M. S. : Results of partial pulpectomy, J. Amer. Dent. Assoc. 30:40-43, 1943.

19) Zander, H. A. and Glass, R. L.: The healing of phenolized pulp exposures, Oral Surg. $2: 803-810,1949$.

20) Weiss, M. B. and Bjorvatn, K. B. : Pulp capping in deciduous and newly erupted permanent teeth of monkeys, Oral Surg. 29:769-775, 1970 .

21) Englander, H. R., Massler, M. et al. : Clinical evaluation of pulpotomy in young adults, J. Dent. Child. 23:48-53, 1956 .

22) Rosenstein, S. N. : Pulp capping in children's teeth, J. Amer. Dent. Assoc. 39:658-669, 1949 .

23）関根永滋・中村靖夫・他：歯内療法に関する臨休病理学的研究，特にユーシノールの露出損傷歯髄に及ぼす 影響について，日保㐘誌 $14: 65-74 ， 1969$.

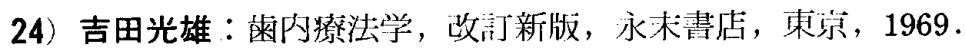

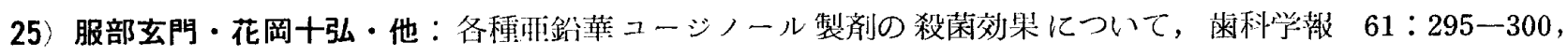
1961 .

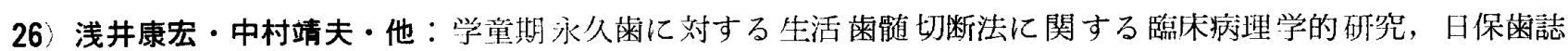
$11: 149-165,1969$. 


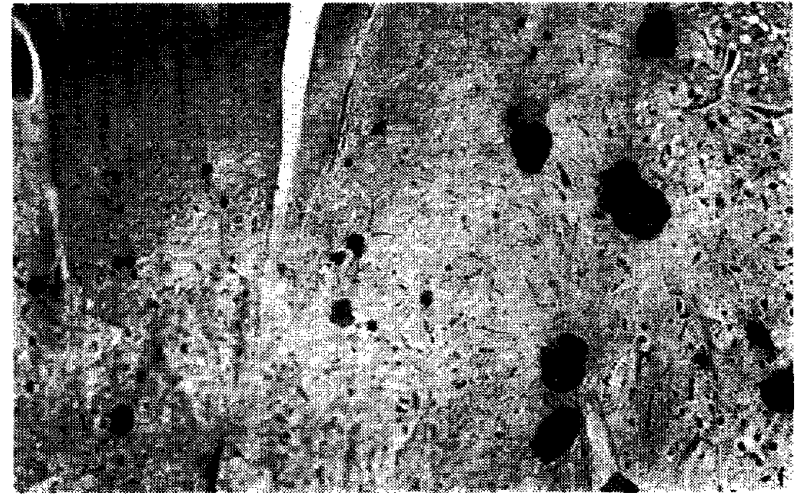

脳 1 Calcipulpe 117 von kóssa 硝酸銀法

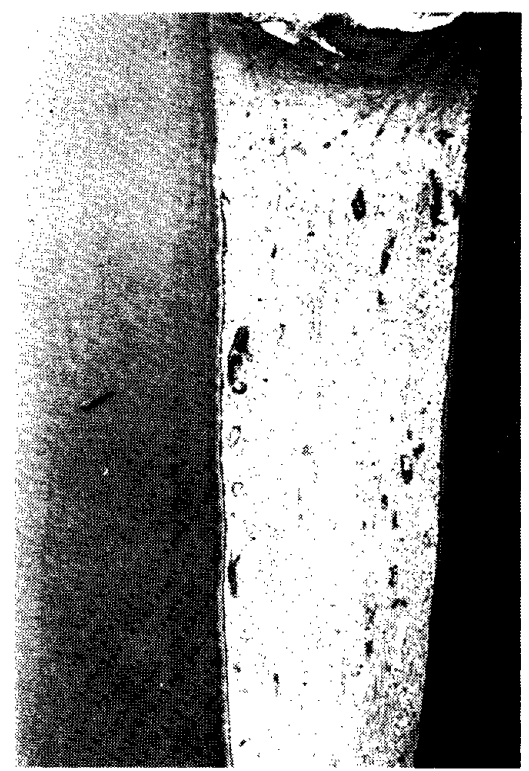

風 2 Calcipulpe 3 H H-E 染色

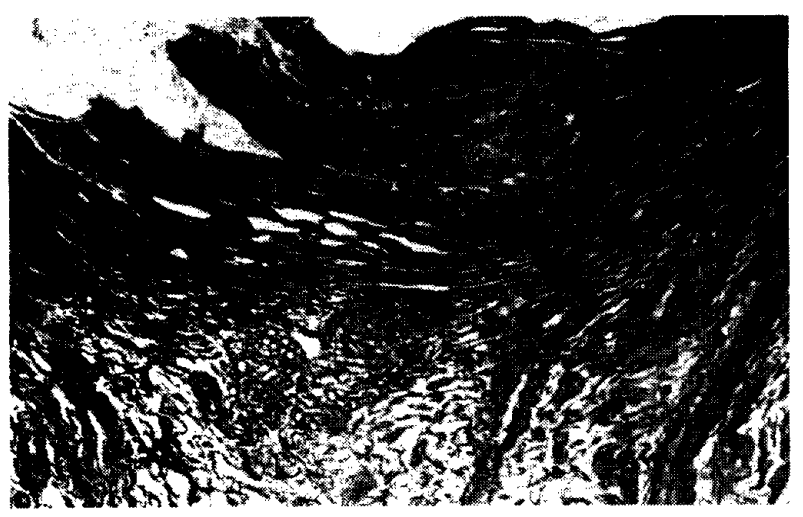

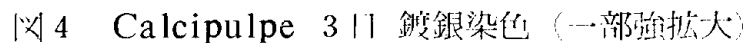

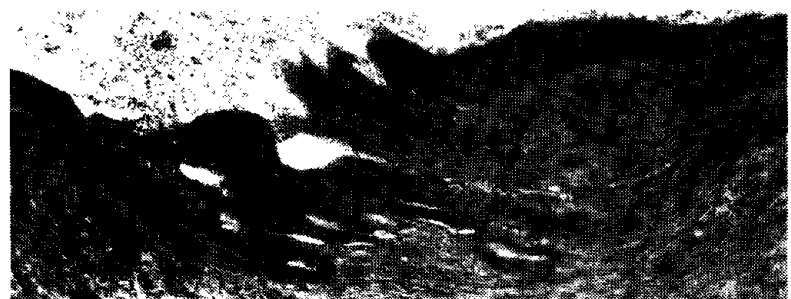

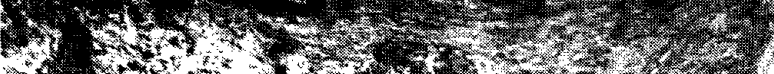

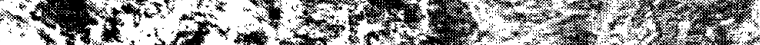

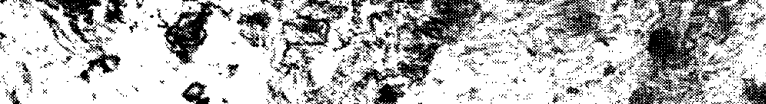
1.

仪 5 Calcipulpe $3 / 1$ Elastica van Gieson

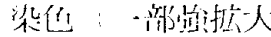

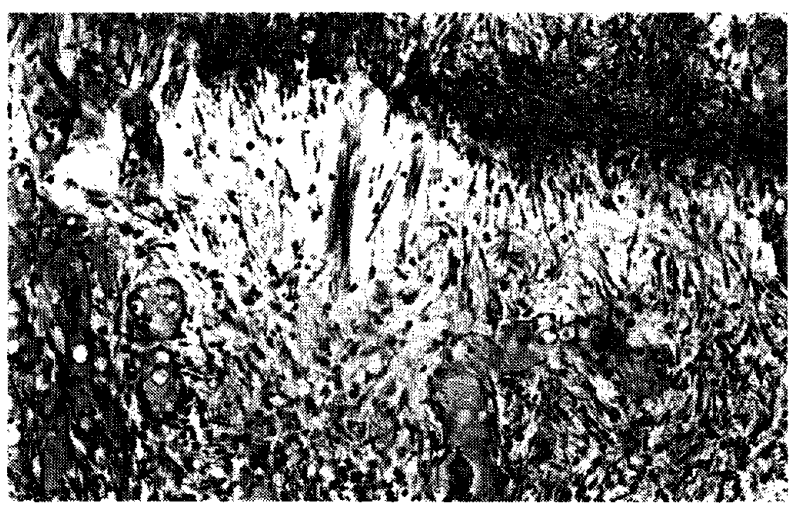

淨6 Calcipulpe 14l! H-E 染色

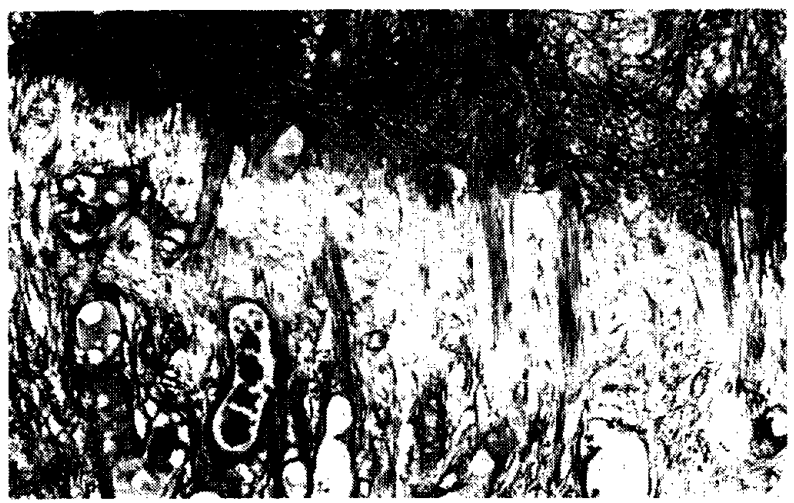

润 7 Calcipulpe 1411 船银染们

図 3 Calcipulpe 3 H H-E 染色 一部强抁大 


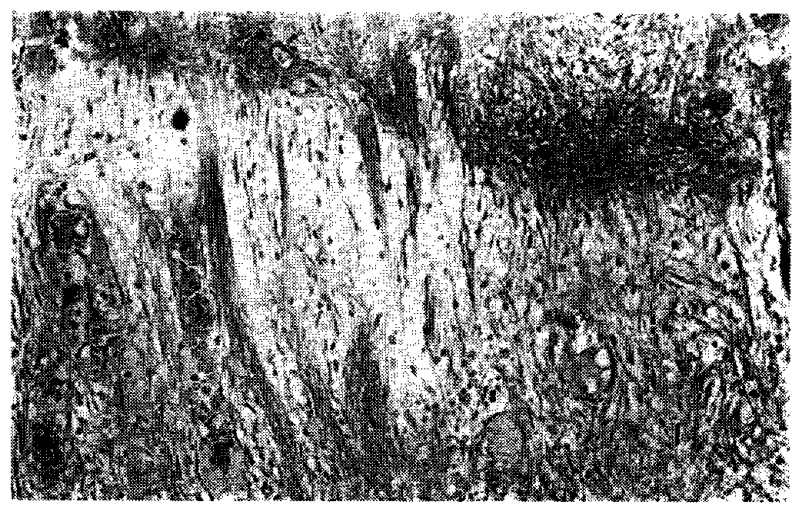

仪 8 Calcipulpe 14f| Elastica van Gieson 染色

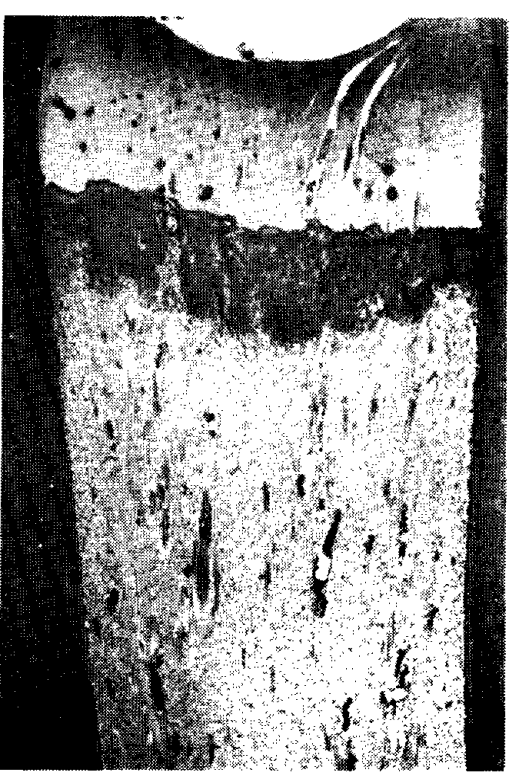

涩 9 Calcipulpe 21日 H-E 染低

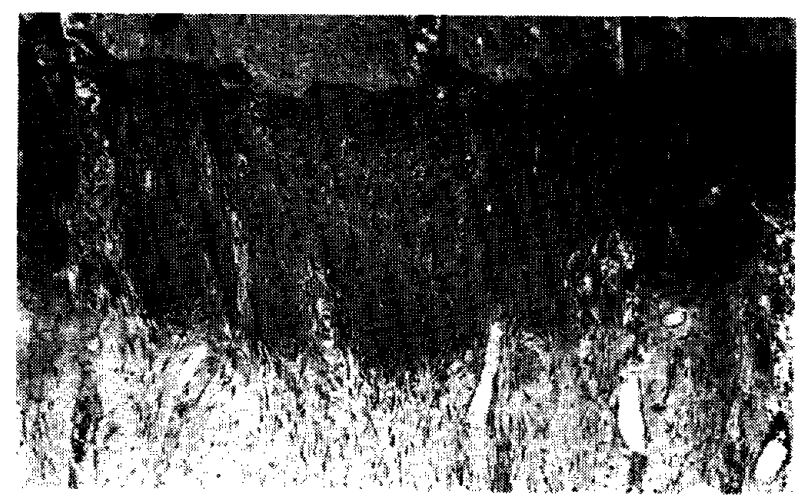

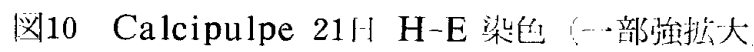

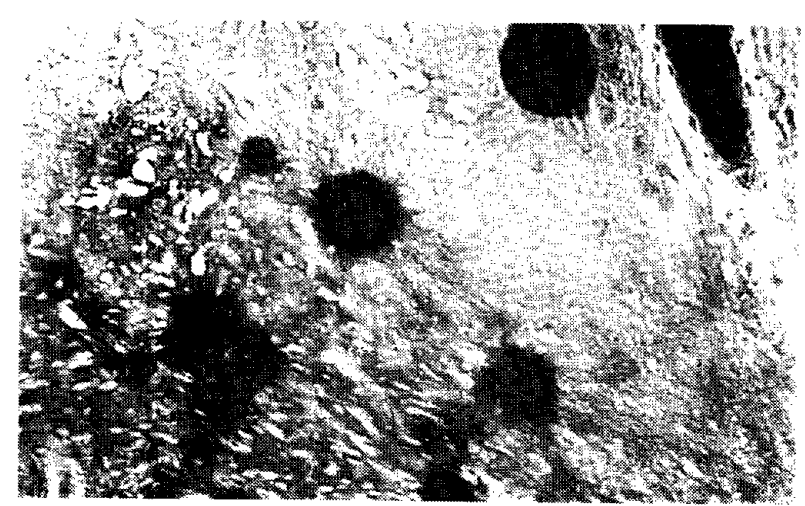

図11 Calcipulpe 211] von kóssa 硝酸鉬注: 一部虽抬人

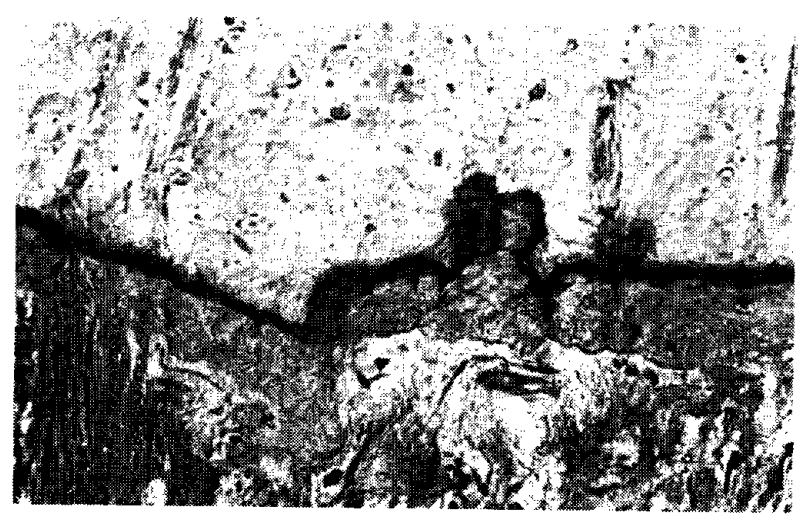

汹12 Calcipulpe 2117 von kóssa 硝婹銀江: 部䖯拉大

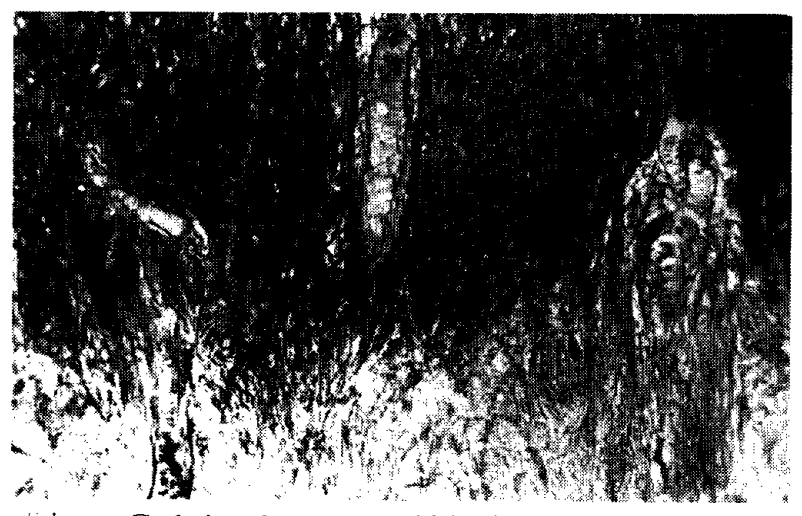

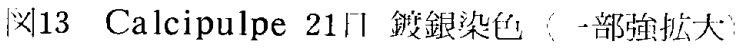

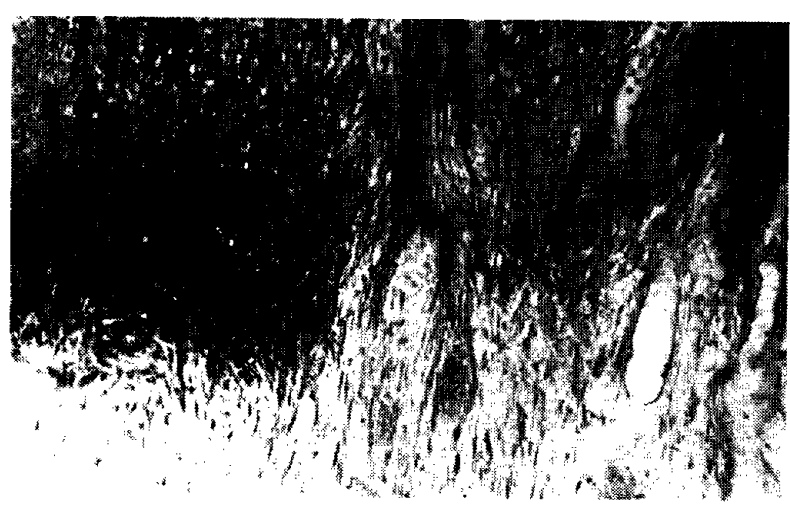

沧14 Calcipulpe 21日 Elastica van Gieson 染色 一部強伀人 


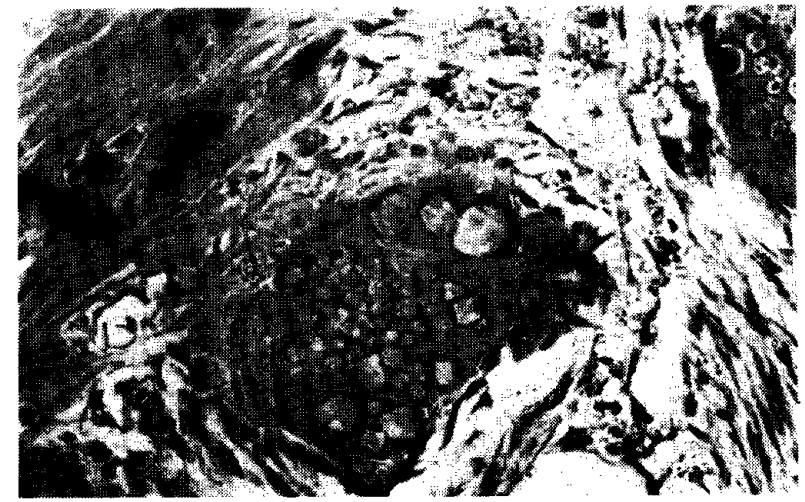

㲸15 Calcipulpe 35H H-E 染色

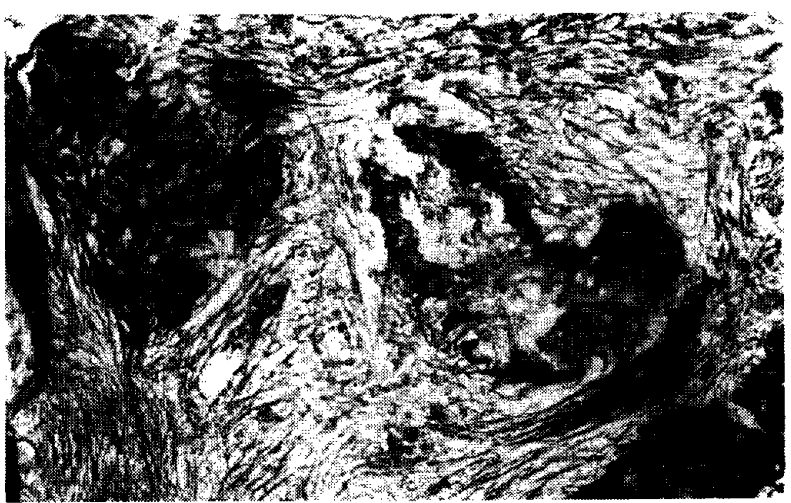

図16 Calcipulpe 35日 鍍銀染岜

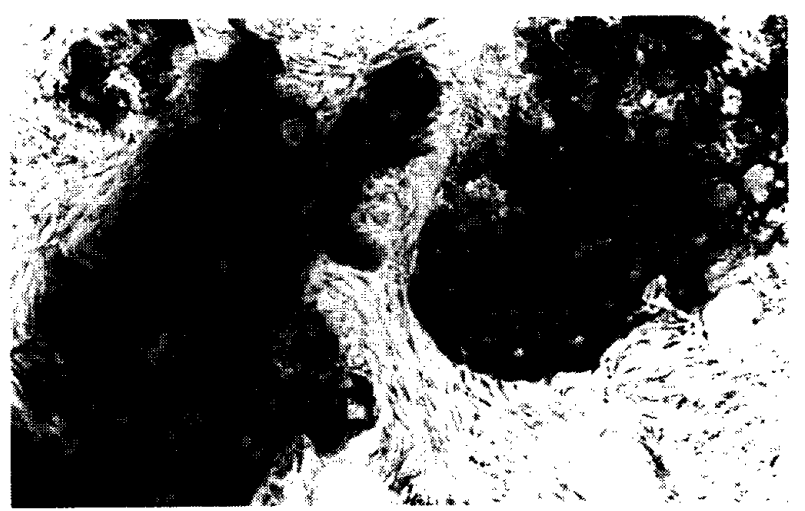

図17 Calcipulpe 35 日 Elastica van Gieson 染色

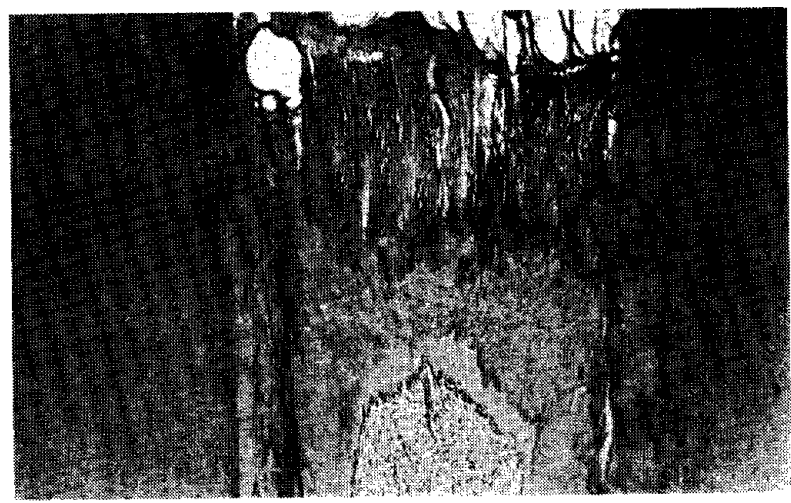

図18 Calcipulpe 92日 H-E 染色

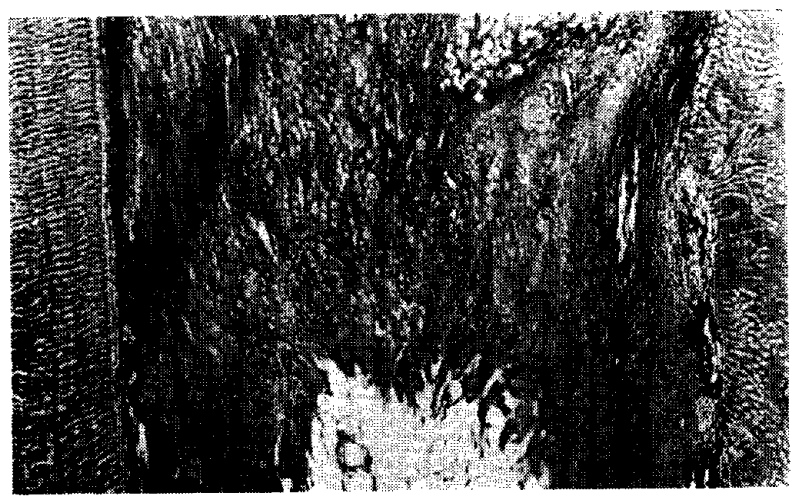

図19 Calcipulpe 92 日鉸銀染色

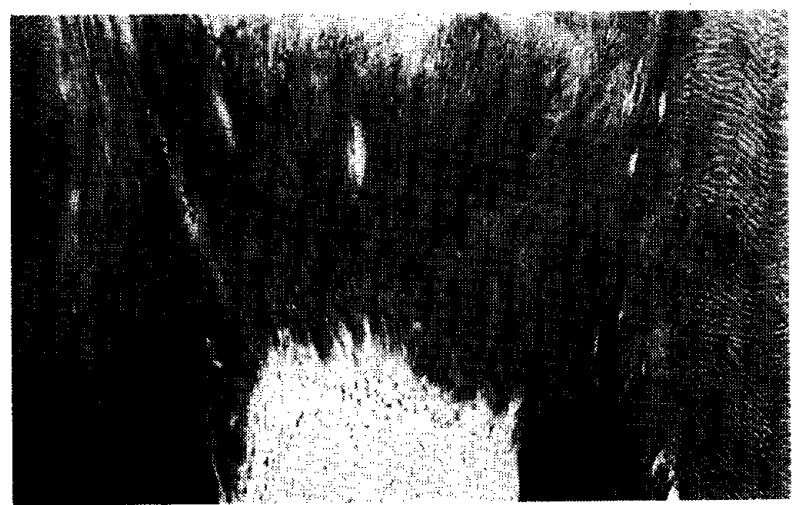

南20 Calcipulpe 92 日 Elastica van Gieson 染色

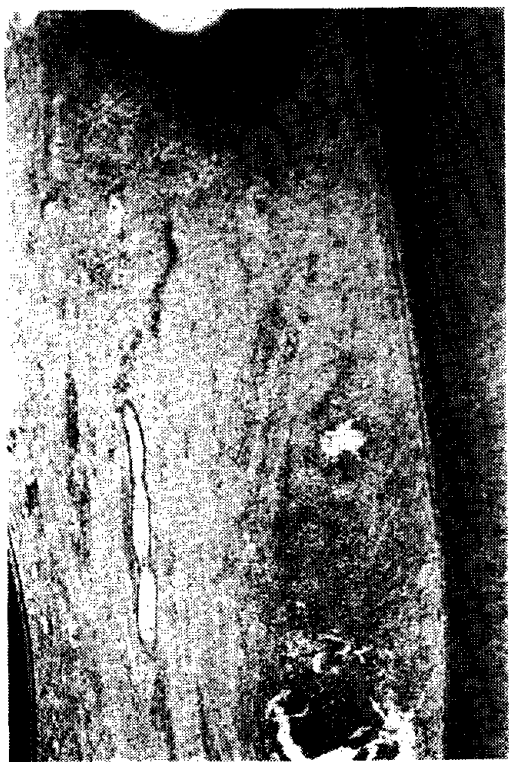

涩21 Propac 3 日 H-E 染色 


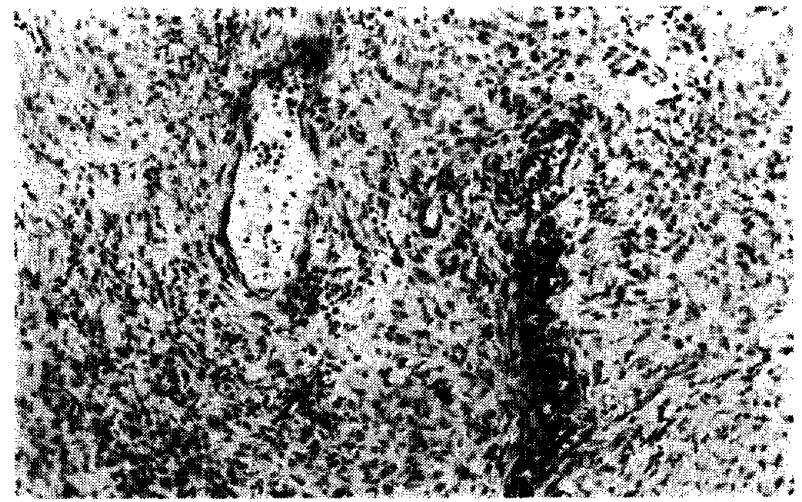

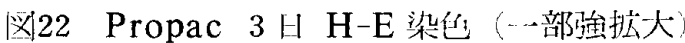

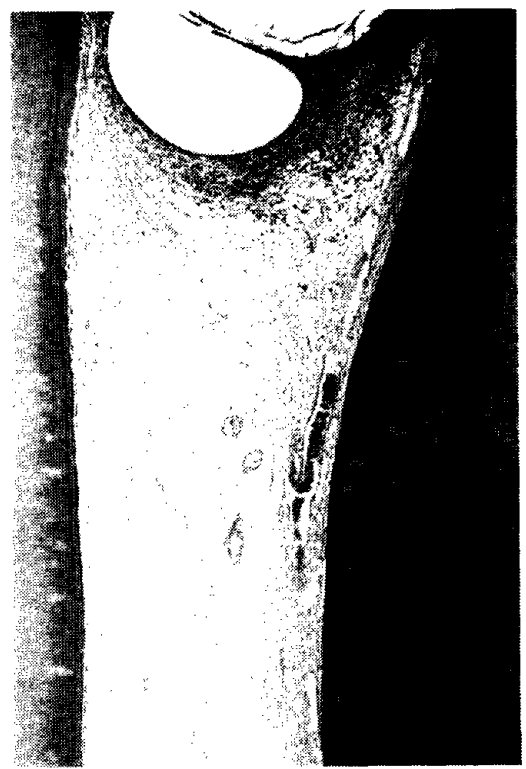

兴|23 Propac 14 H H-E 染出

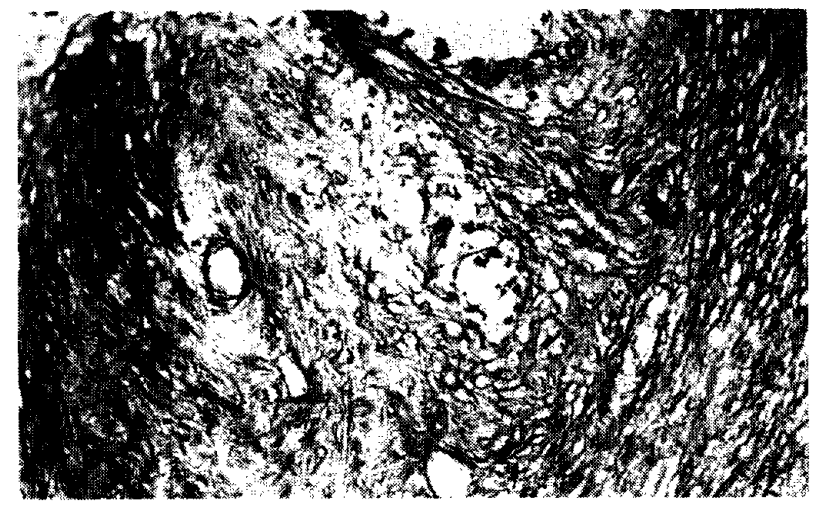

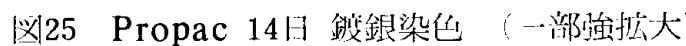

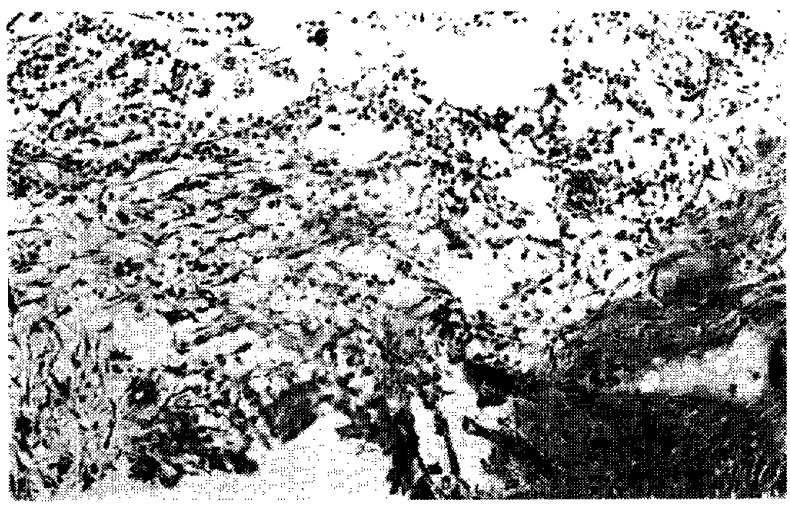

汶26 Propac 14|.| Elastica van Gieson 染他 (一部強㹡大

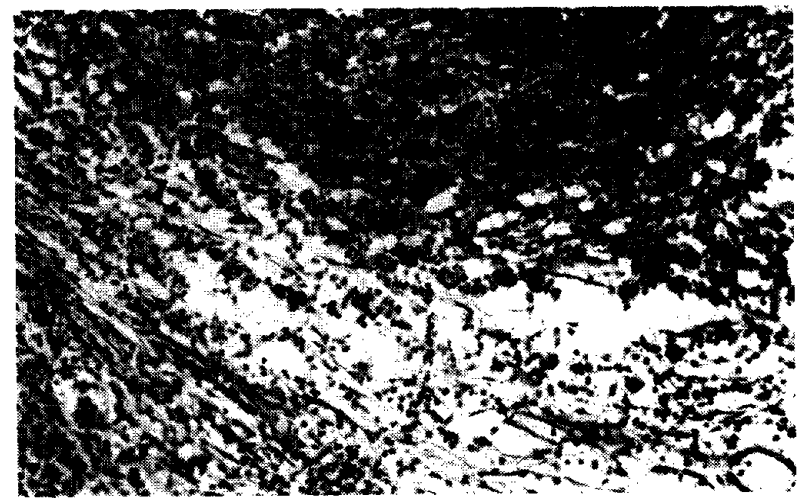

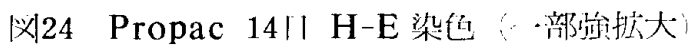

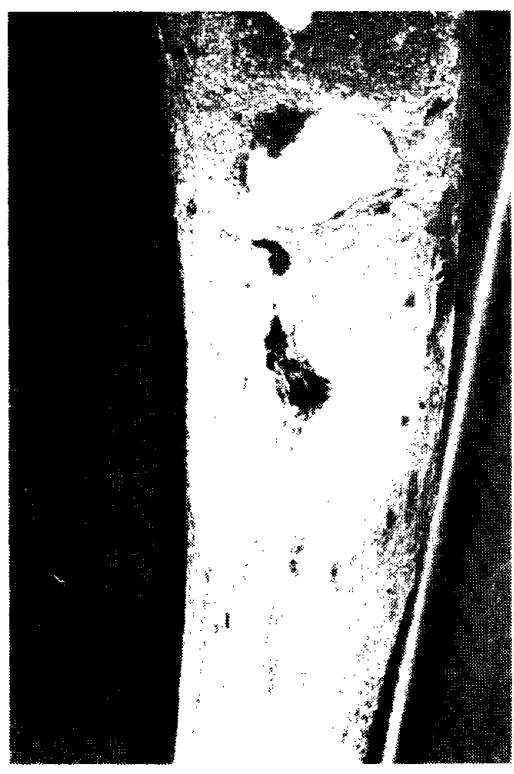

刚27 Propac 35H H-E 染壬 


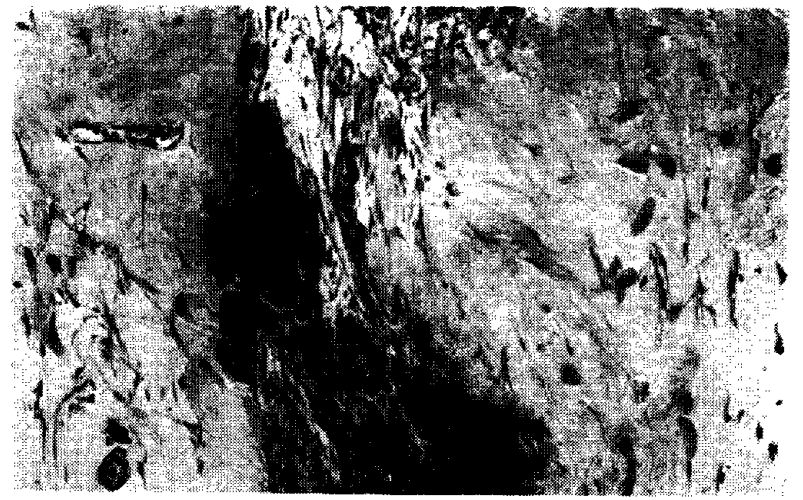

図28 Propac 35日 H-E 染出（一部強昖大）

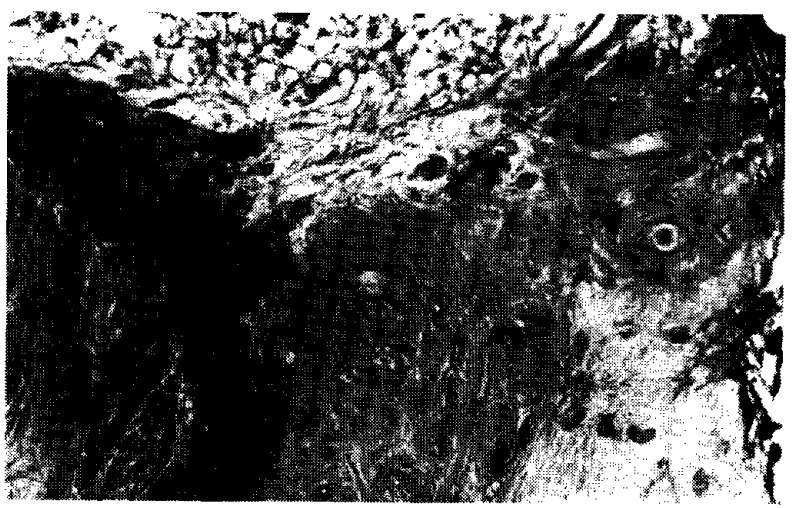

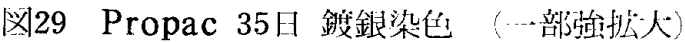

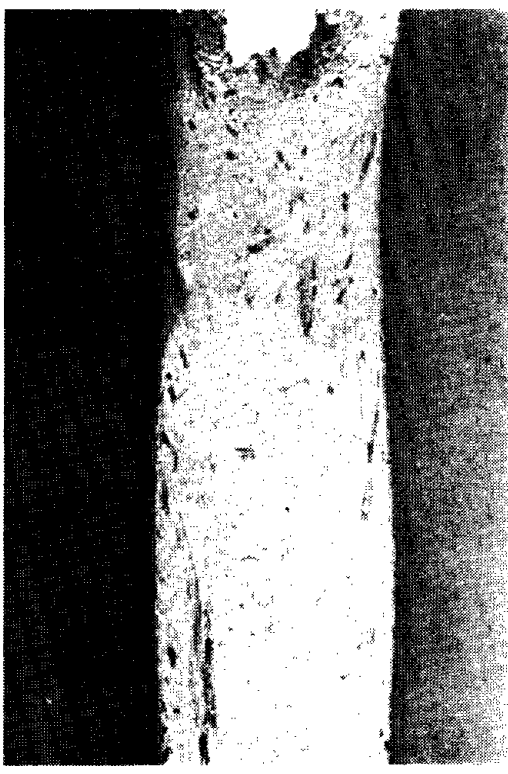

図31 Propac 92日 H-E 染色

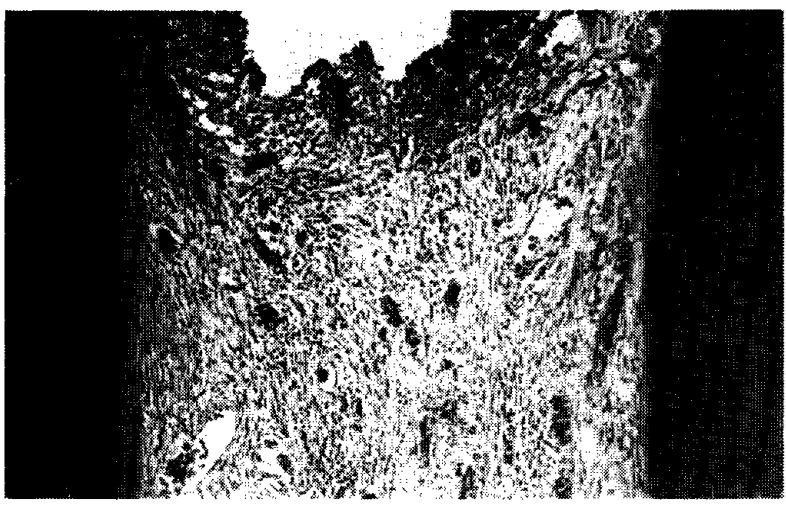

図32 Propac 92日 H-E 染色（一部強拉大）

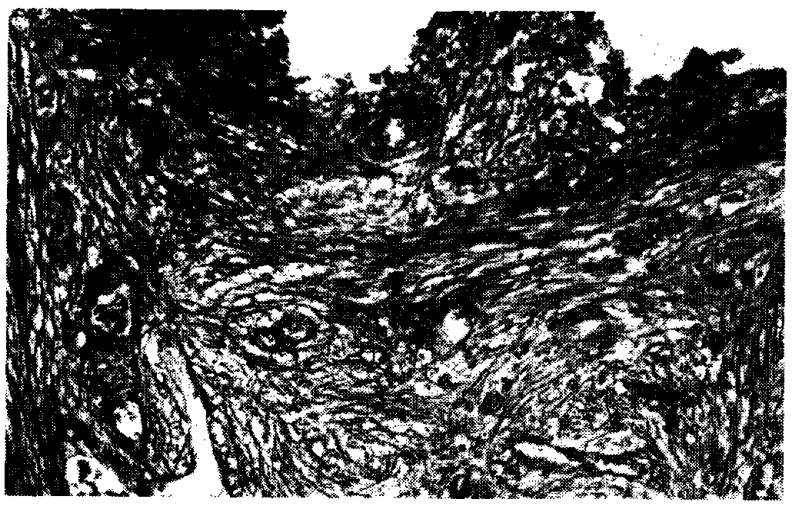

図33 Propac 92日 鉸銀染色（一部強拡大） 


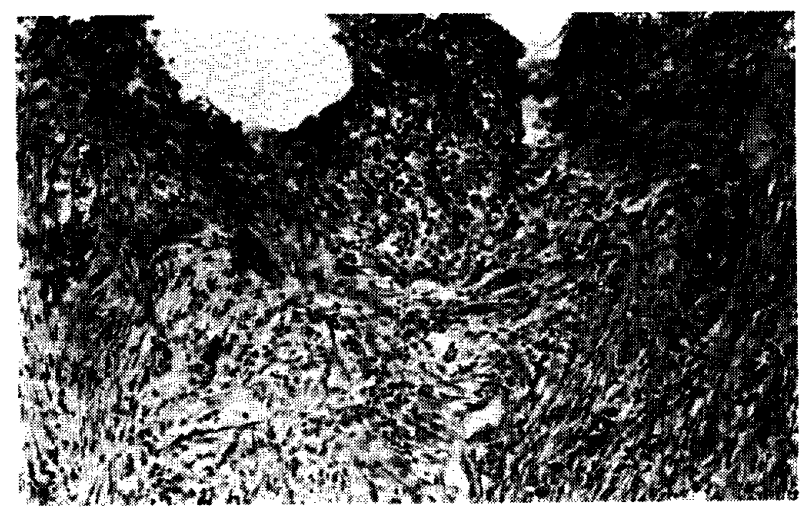

汹34 Propac 92日 Elastica van Gieson 染任 (一部强扰人)

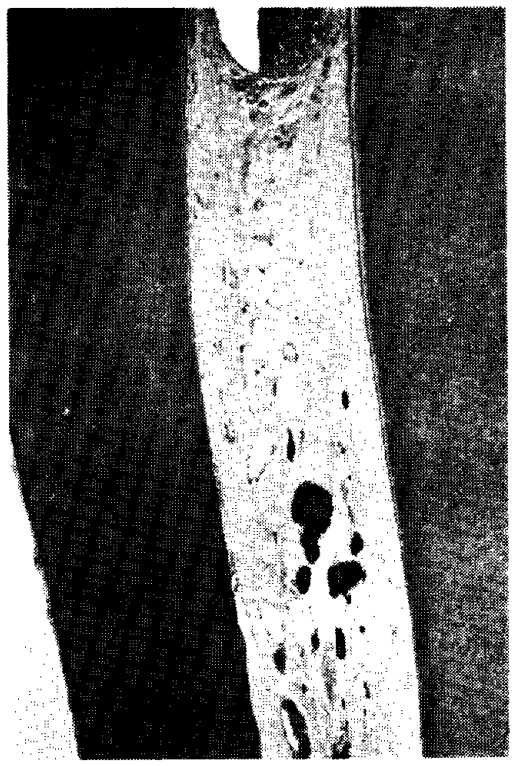

㳚35 Topdain 3 H $\mathrm{H}-\mathrm{E}$ 染兒

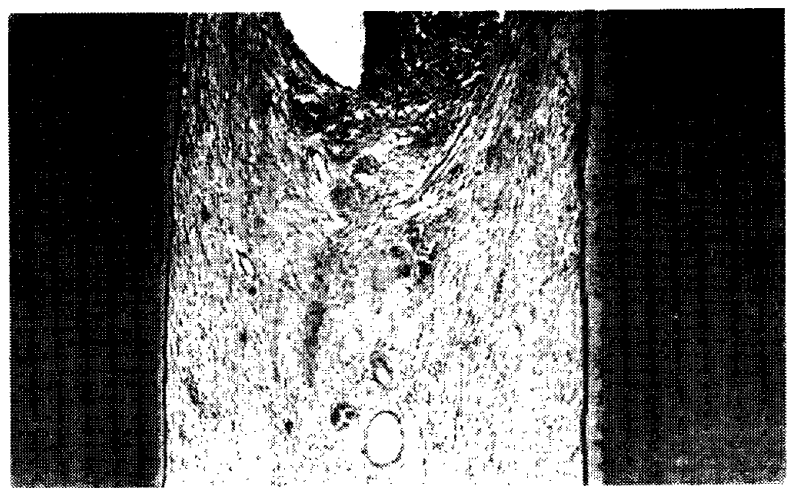

忷36 Topdain 3 日 H-E 染色（一部溞桩大）

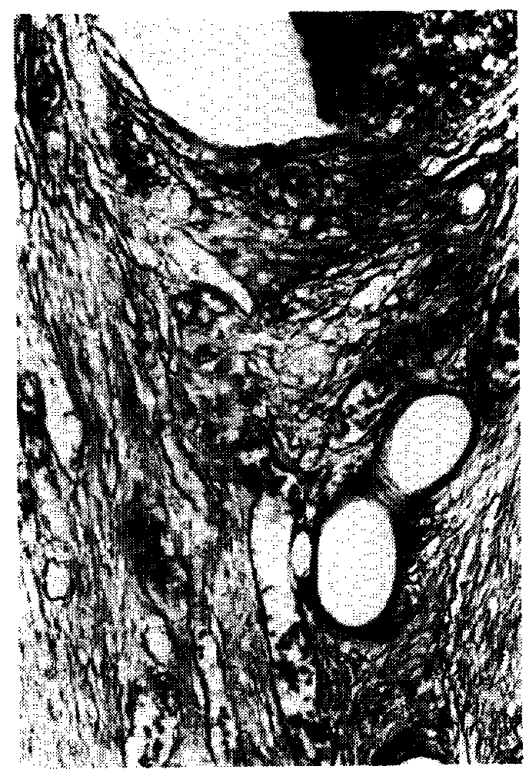

㥗37 Topdain 3 日 鍍銀染色 (一部強拉大)

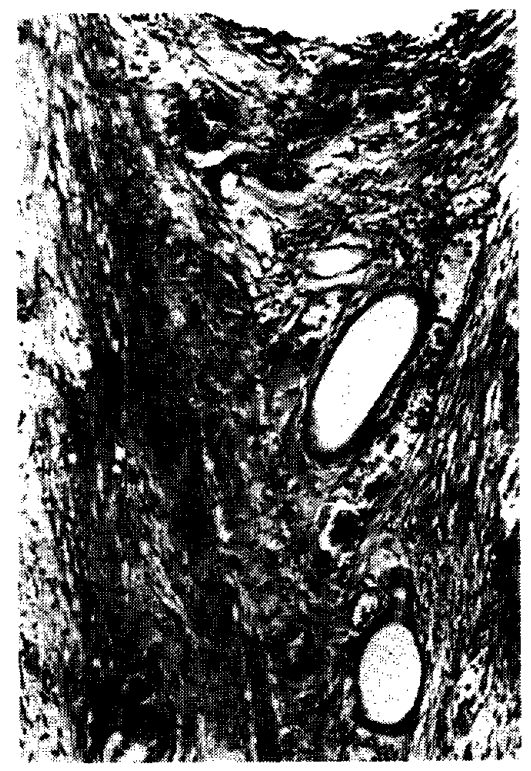

粄38 Topdain 3 日 Elastica van Gieson 染色 (一部強拨大) 


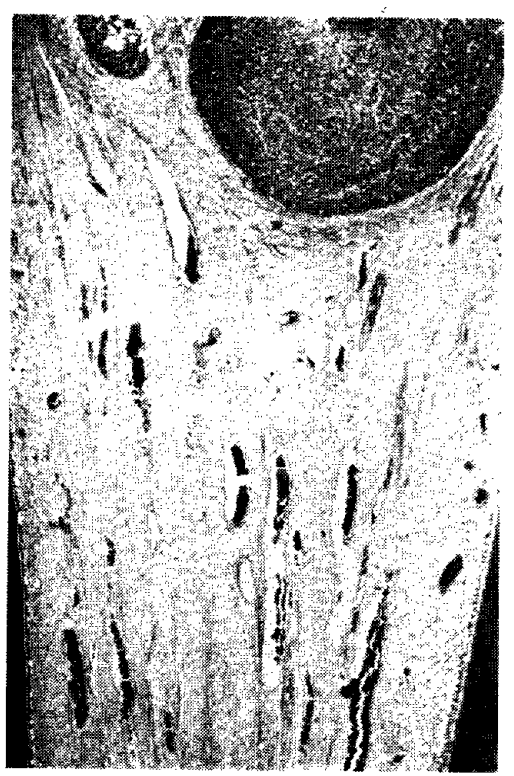

㲸39 Topdain 14H H-E 染色

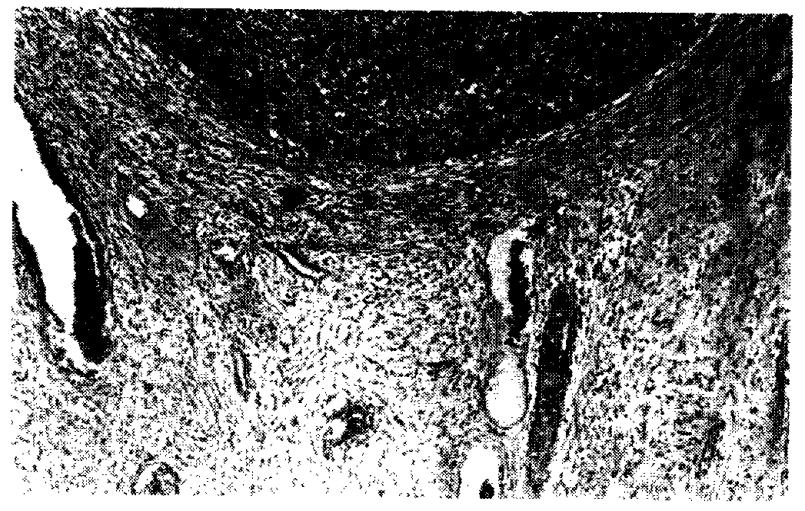

図40 Topdain 14日 H-E 染色(一部強拡大

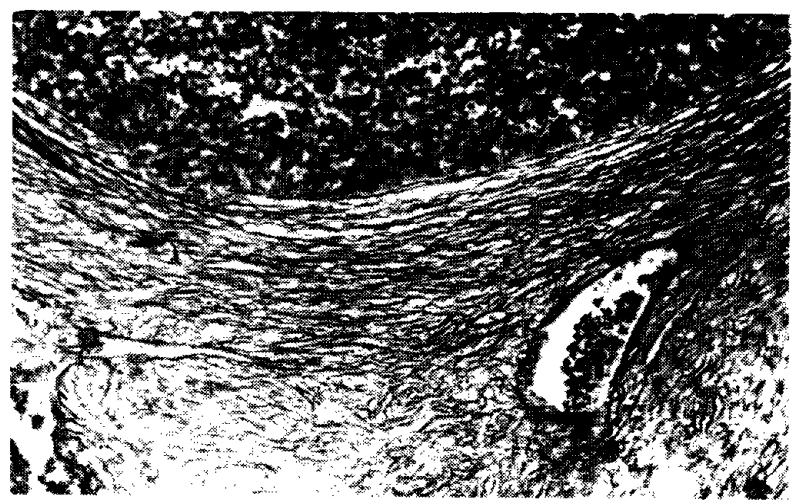

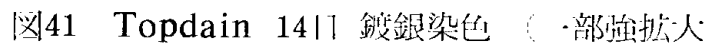

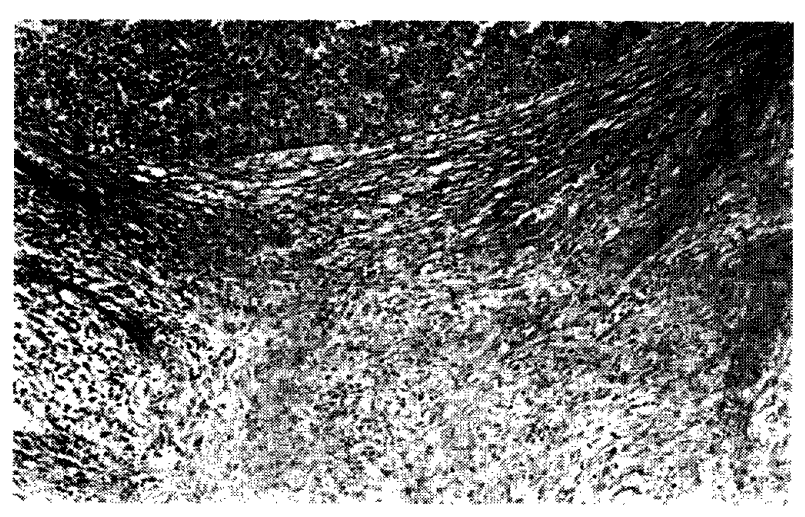

㲸|42 Topdain 14月 Elastica van Gieson 染伯 一部筥挫人

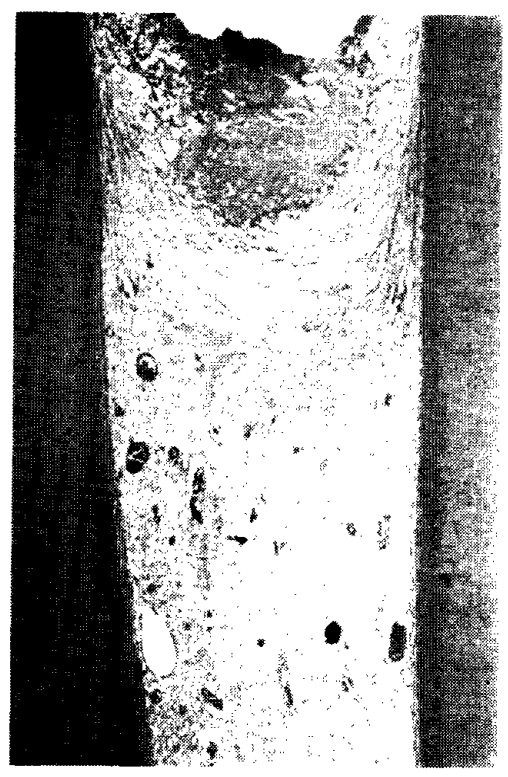

㲸|43 Topdain 35 H-E 染他

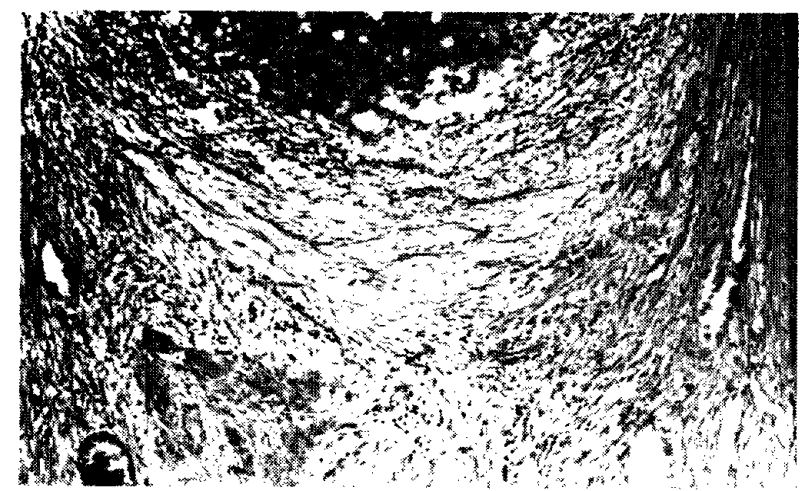

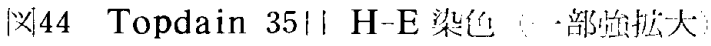




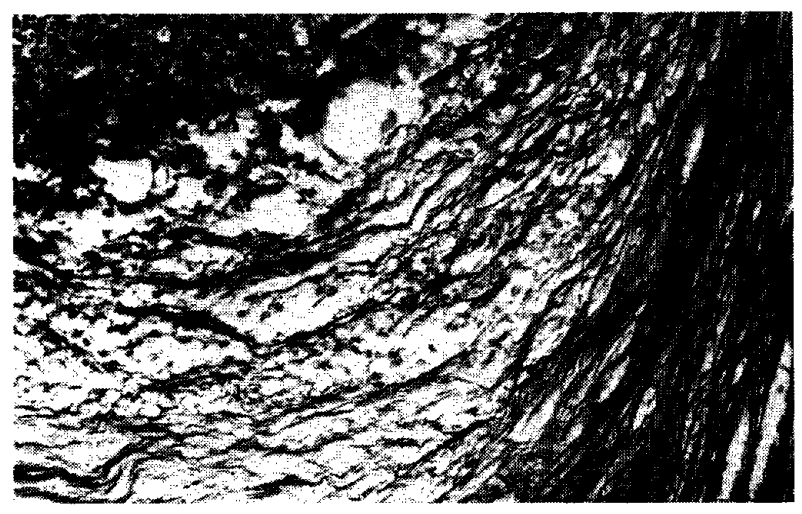

図45 Topdain 35日 鋌銀染色（一部強桩大）

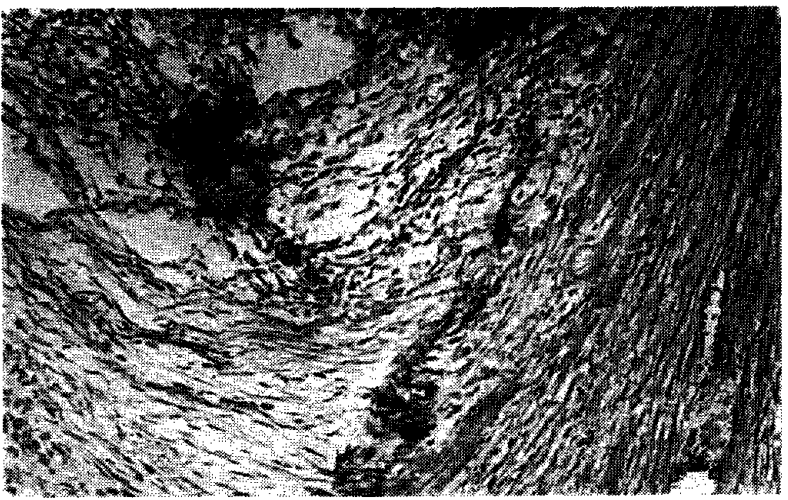

网46 Topdain 35日 Elastica van Gieson 染色 (一部強拨大)

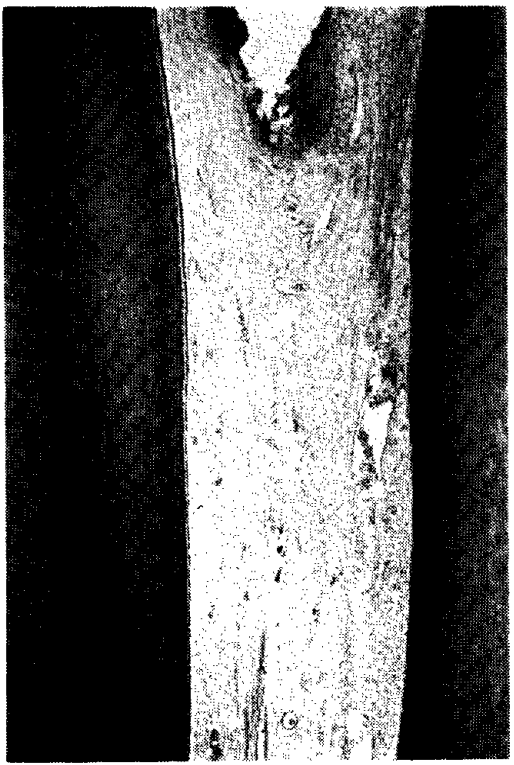

威47 Topdain 92日 H-E 染色

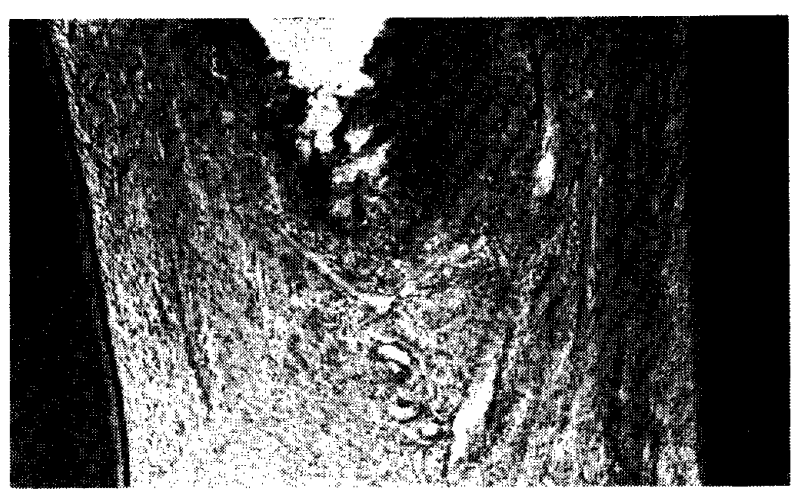

龱48 Topdain 92日 H-E 染色（一部強拢大） 